\title{
Review
}

\section{Calcium Dyshomeostasis in Alzheimer's Disease Pathogenesis}

\author{
Roberta Cascella (D) and Cristina Cecchi * (D) \\ Department of Experimental and Clinical Biomedical Sciences, University of Florence, 50134 Florence, Italy; \\ roberta.cascella@unifi.it \\ * Correspondence: cristina.cecchi@unifi.it
}

Citation: Cascella, R.; Cecchi, C. Calcium Dyshomeostasis in Alzheimer's Disease Pathogenesis. Int. J. Mol. Sci. 2021, 22, 4914. https: / / doi.org/10.3390/ ijms22094914

Academic Editor: Botond Penke

Received: 6 April 2021

Accepted: 30 April 2021

Published: 6 May 2021

Publisher's Note: MDPI stays neutral with regard to jurisdictional claims in published maps and institutional affiliations.

Copyright: (C) 2021 by the authors. Licensee MDPI, Basel, Switzerland. This article is an open access article distributed under the terms and conditions of the Creative Commons Attribution (CC BY) license (https:/ / creativecommons.org/licenses/by/ $4.0 /)$.

\begin{abstract}
Alzheimer's disease (AD) is the most common age-related neurodegenerative disorder that is characterized by amyloid $\beta$-protein deposition in senile plaques, neurofibrillary tangles consisting of abnormally phosphorylated tau protein, and neuronal loss leading to cognitive decline and dementia. Despite extensive research, the exact mechanisms underlying AD remain unknown and effective treatment is not available. Many hypotheses have been proposed to explain AD pathophysiology; however, there is general consensus that the abnormal aggregation of the amyloid $\beta$ peptide $(\mathrm{A} \beta)$ is the initial event triggering a pathogenic cascade of degenerating events in cholinergic neurons. The dysregulation of calcium homeostasis has been studied considerably to clarify the mechanisms of neurodegeneration induced by $\mathrm{A} \beta$. Intracellular calcium acts as a second messenger and plays a key role in the regulation of neuronal functions, such as neural growth and differentiation, action potential, and synaptic plasticity. The calcium hypothesis of AD posits that activation of the amyloidogenic pathway affects neuronal $\mathrm{Ca}^{2+}$ homeostasis and the mechanisms responsible for learning and memory. $\mathrm{A} \beta$ can disrupt $\mathrm{Ca}^{2+}$ signaling through several mechanisms, by increasing the influx of $\mathrm{Ca}^{2+}$ from the extracellular space and by activating its release from intracellular stores. Here, we review the different molecular mechanisms and receptors involved in calcium dysregulation in AD and possible therapeutic strategies for improving the treatment.
\end{abstract}

Keywords: protein aggregation; amyloid $\beta$ peptide $(\mathrm{A} \beta)$; toxic oligomers; amyloid fibrils; tau protein; neurodegeneration; ionic dysregulation; glutamatergic receptors; NMDA; AMPA

\section{Alzheimer's Disease}

Alzheimer's disease (AD) is the most common cause of age-related neurodegenerative disease, which is characterized by progressive memory loss, cognitive dysfunction, language disorders, and personality changes [1]. While there is no cure or a way to stop or slow AD progression, there are drug and non-drug options that may help to treat symptoms [2,3]. In particular, the FDA-approved drugs are acetylcholine esterase (AChE) inhibitors and Nmethyl D-aspartate receptor (NMDAR) blocker, but they cause a variety of side effects [4-6]. In 2015, around 46.8 million individuals worldwide had dementia, increasing to 50 million people in 2017 and expecting to rise exponentially in the next few years [7]. Numerous research studies have tried to elucidate the mechanisms of the pathogenesis and development of this disease, and multiple hypotheses have been postulated. The pathogenesis of $\mathrm{AD}$ involves the massive extracellular deposition of amyloid- $\beta(\mathrm{A} \beta)$, forming cores of senile plaques in the brain parenchyma, and intracellular accumulation of the abnormally hyperphosphorylated tau proteins, forming neurofibrillary tangles (NFTs) [2,8-11]. A $\beta$ and NFTs induce the loss of neurons and synaptic density by enhancing the inflammation process, oxidative stress and the occurrence of cerebral microvascular disease [12]. A $\beta$ plaque also promotes the senescence of neural stem/progenitor cells by affecting forebrain and hippocampal neurogenesis [13]. Emerging evidence suggests the existence of additional molecular pathophysiological pathways, including axonal disintegration [14], synaptic dysfunction and degeneration [15], innate immune responses and neuroinflammation [16,17], 
vascular dysregulation [12,18], and brain metabolic dysfunction [19] across the different stages of AD.

Although extracellular A $\beta$ plaques and NFTs in the brain are hallmarks of AD, the multiple mechanisms related to the disease are still unclear. The amyloid cascade was considered for a long time as a dominant model for AD pathogenesis [10]. According to this hypothesis, the starting event in $\mathrm{AD}$ is the aggregation and subsequent deposition of the $A \beta$ peptide in the brain $[20,21]$, resulting in the hyperphosphorylation of tau into NFTs and, ultimately, the degeneration of neurons. This hypothesis is supported by the identification of mutations in the genes encoding amyloid precursor protein (APP) and the presenilin proteins (PS1 and PS2), causing an overproduction of $\mathrm{A} \beta$ or an increase in its aggregation potential [22-24]. More recently, accumulating evidence suggests that the hyperphosphorylation and polymerization of tau into NFTs have a synergistic effect with $\mathrm{A} \beta$ on $\mathrm{AD}$ pathogenesis [25].

There are two major forms of AD: the sporadic or late-onset form (SAD), the most common one, and the familial or early-onset form (FAD), representing less than $5 \%$ of the cases [26]. Although there are genetic and pathological differences between the two forms of AD, they show remarkable similarities in their pathophysiology and clinical symptoms [27]. Studies on animal models carrying APP, PS1 or PS2 mutations suggest that intervention at the embryonic stage is beneficial for inducing synaptic plasticity [28] Nevertheless, while APP, PS1 and PS2 gene mutations were identified as responsible for autosomal-dominant AD, the etiology of SAD still remains elusive. Indeed, SAD appears to be influenced by the combined action of multiple genetic susceptibilities and environmental risk factors [29]. In addition, early diagnosis or intervention aimed at the high-risk factors, such as type 2 diabetes mellitus and hyperhomocysteinemia, may be suitable [30-33]. One of the major genetic risk factors of SAD is the Epsilon $4(\varepsilon 4)$ allele of the apolipoprotein $\mathrm{E}$ gene (APOE4), which is involved in the aggregation and clearance of $A \beta$ and in cholesterol homeostasis [34]. Different polymorphic forms of APOE4 have been reported and, among them, the $\varepsilon 4$ form was found to correlate with a major risk of AD, both in homozygosis and heterozygosis [35]. Structural and functional neuroimaging studies found hippocampal and medial-temporal lobe atrophies in both types of $\mathrm{AD}$, which also share temporoparietal hypometabolism and sporadic memory and judgment impairment. In addition, myoclonus and seizures are also frequently observed. Regarding symptoms, late-onset forms show typical manifestations of dementia, with memory impairment and executive dysfunction interfering with daily life activities. On the other hand, early-onset forms have atypical symptoms, including language, visual, practice, or executive problems, that appear more pronounced with respect to memory deficits [9].

\section{$A \beta$ Peptide and Tau Protein: Synergistic Effects}

The $A \beta$ peptide is generated from the endosomal proteolytic cleavage of the APP by $\gamma$-secretase and $\beta$-site APP cleaving enzyme 1 (BACE1), which catalyzes the rate-limiting step [36]. During the intracellular trafficking of APP into the endocytic compartment from the plasma membrane, APP is first cleaved by BACE1, followed by $\gamma$-secretase cleavage of the stub of APP at different positions, leading to the production of $\mathrm{C}$-terminal ends of $A \beta$ of various lengths such as $A \beta 40$ and $A \beta 42[37,38]$. $A \beta 42$, with respect to $A \beta 40$, is more hydrophobic, prone to amyloid formation, and is the initial and predominant species found in senile plaques [39]. In healthy brains, the non-amyloid pathway requires APP to be first cleaved by $\alpha$-secretase, producing an extracellular secretory fragment (sAPPa) and a membrane-bound carboxy-terminal fragment, which is then cleaved by $\gamma$-secretase into small fragments that can be completely degraded. Jonsson and coworkers showed that the A672T mutation in the APP gene causes a decrease in the $\beta$-cleavage of APP, resulting in protection against AD [40]. By contrast, several gene mutations on APP have been identified to promote $A \beta$ production. In addition, various genetic studies have demonstrated that autosomal-dominant familial AD mutations in PS1 and PS2, the catalytic subunit of $\gamma$-secretase, cause the increase in $A \beta 42$ production, suggesting the 
involvement of $\gamma$-secretase in the pathogenesis of AD [41-44]. During endocytosis from the plasma membrane, $\gamma$-secretase cleaves its substrate C99, which is the C-terminal fragment of APP, to generate A $\beta$ in the endosomes. Recently, it has been reported that phosphatidylinositol binding clathrin assembly protein (PICALM), a genetic risk factor of $\mathrm{AD}$, affects $\mathrm{A} \beta$ production through the regulation of the subcellular localization of $\gamma$-secretase [45]. Following the production of A $\beta$ peptides through the cleavage of APP by $\beta$ and $\gamma$ secretases and the secretion in the external environment, an aggregation process produces a variety of oligomeric forms that act as active neurotoxins, causing neuronal dysfunction, the loss of synaptic connections, and cell death. In particular, $\mathrm{A} \beta$ peptides undergo a conformational change, forming $\beta$-sheet-rich oligomeric complexes of different sizes that eventually develop into amyloid-type fibrils forming cores of senile plaques in the brain parenchyma [46-48].

The tau protein is an axonal microtubule-associated protein that is distributed in the axons of neurons and is one of the main components of the cytoskeleton [49]. Tau is known to undergo several post-translational modifications, such as phosphorylation, acetylation, methylation, glycation, polyamination, glycosylation, nitration, ubiquitination, sumoylation, isomerization, and oxidation, most of which occur at multiple residues along the protein [50]. The most studied post-translational modification of tau is phosphorylation, as its abnormal phosphorylation is associated with several tauopathies [49]. The hyperphosphorylation of tau is known to be involved in the onset and progression of $A D$, leading to the aggregation and development of NFTs commonly found inside neurons of AD patients [51]. The formation of cytoplasmic NFTs compromises microtubules and causes the disruption of several cellular pathways, including proliferation, differentiation and protein trafficking [52]. Numerous research data from multiple laboratories demonstrated that misfolded tau can be released from neurons and taken up by connected cells, leading to a spreading process between cells that might then recruit endogenous tau to the misfolded state [53]. This model is in agreement with those of $\alpha$-synuclein in Parkinson's disease and other neurodegenerative disorders [53,54].

A dominant theory for the incidence of $\mathrm{AD}$ is the "amyloid hypothesis", which describes a complex sequence of pathogenic events responsible for neurodegeneration [55-60]. According to this hypothesis, the aberrant accumulation of the $\mathrm{A} \beta$ peptide, following the amyloidogenic processing of the APP, results in the production of cytotoxic complexes and its deposition in various brain areas. This accumulation triggers a cascade of pathogenic events, including the alteration of ionic homeostasis, oxidative stress, inflammation and vascular damage. $A \beta$ complexes are also responsible for a wide range of biochemical and structural changes in the nearby neurites and cell bodies, culminating in neuronal dysfunction and synapse loss [61]. AD pathogenesis has been prevalently associated with the progressive $A \beta$ accumulation in the brain parenchyma and the formation of senile plaques. The presence of $\mathrm{A} \beta$ peptides in senile plaques of $\mathrm{AD}$ patients [62], as well as the location of the APP gene on chromosome 21, which causes Down's syndrome [20], have originally reinforced the amyloid cascade hypothesis. Nevertheless, recent evidence suggests that the $\mathrm{A} \beta$ peptide can act as a "seed," in the development rather than the progression of the disease [63]. In addition, the amyloid hypothesis was extensively criticized because of many reasons, including that APP mutations in AD patients have a low frequency, many Down's syndrome patients did not develop AD and the presence of presenilin mutations did not correlate with the increased $A \beta$ production [64]. Furthermore, the $A \beta$ peptide is an important metabolite whose beneficial function should be identified together with that of APP, and A $\beta$ deposition does not correlate with the severity of dementia as along with tangle density or synapse loss. Further investigations in AD mouse models demonstrated that the accumulation of $A \beta$ fibrils in senile plaques did not correlate with neuronal cell death [65], suggesting that $A \beta$ oligomers might be the key cytotoxic agents rather than the fibrillar form. Indeed, even though the $A \beta$ peptide has been first identified as the main component of the extracellular amyloid plaques, it is now well established that the oligomeric species accumulating intracellularly, as dimers and trimers, are more toxic 
than the extracellular $A \beta$ fibrils [66]. Moreover, several studies demonstrated that $A \beta$ oligomers have a key role in synaptic dysfunction and neuronal alterations [67-70], leading to cognitive impairment many years before the formation of amyloid plaques and neuronal death $[71,72]$. The specific mechanisms for $A \beta$ peptide-induced cytotoxicity have not yet been completely elucidated. Several studies have suggested that the reuptake of extracellular $\mathrm{A} \beta$ into neurons may lead to neuronal damage and neurotoxicity [73]. The toxicity of $A \beta$ oligomers involves the alteration of the plasma membrane [74-76], ion dysregulation $[74,77,78]$, oxidative stress [79-85], the inhibition of proteasomal degradation [86,87], the impairment of autophagy $[87,88]$ and inflammation [89-91]. However, the multifactorial nature of $\mathrm{AD}$ points out that the $\mathrm{A} \beta$ peptide might be required but not sufficient for the development of the disease [92]. This could explain the failure of anti-A $\beta$ clinical trials and suggest that the role of tau needs to be reconsidered [25].

According to the "tau hypothesis", the intracellular NFTs, mainly composed of abnormally phosphorylated and aggregated tau proteins, are considered as the principal effectors of neuronal loss and memory impairment in $\mathrm{AD}$ via the impairment of axonal transport. In contrast to the view that there is no particular interaction between $A \beta$ and tau, recent experimental and clinical evidence supports a strong $A \beta$-tau synergy [25]. Indeed, the presence of $A \beta$ was found to enhance tau phenotypes throughout the disease course [93], and the functional consequences of such interplay occur in late stages of the disease [94]. In particular, the researchers noticed that the propagation of tau is always associated with the presence of $A \beta$ plaques [54]. Furthermore, in human postmortem tissues, the presence of $A \beta$ was found to promote the formation of a specific form of hyperphosphorylated tau, which is particularly prone to spread [95]. These data are in agreement with PET results showing that tau accumulation in the cortex of cognitively normal older individuals was accelerated in the presence of $A \beta$ [96]. The synergistic association between $A \beta$ and tau was also demonstrated in the CSF, where both total tau and phosphorylated tau levels correlated with cognitive performance only when $A \beta$ deposition was contemporaneously present [97]. Thus, neither the amyloid nor tau hypotheses are sufficient to explain all the pathological mechanisms responsible for $\mathrm{AD}$ pathogenesis $[25,98]$, but rather a unique theory taking into account the synergistic effects of both would explain many pathogenic processes occurring during AD progression.

\section{Regulation of Ionic Homeostasis}

The regulation of ionic homeostasis is crucial for several neuronal functions. Indeed, ion gradients provide the driving force for important intra- and inter-cellular communications within neuronal networks. In particular, sodium $\left(\mathrm{Na}^{+}\right)$entry into neurons is essential for the propagation of action potentials, whereas $\mathrm{Ca}^{2+}$ signaling is involved in neurotransmitter release, synaptic plasticity, gene expression and other important neuronal functions [99-101]. $\mathrm{Ca}^{2+}$ concentration is finely regulated by cell surface receptors, channels, pumps, antiporters, $\mathrm{Ca}^{2+}$ buffers, and $\mathrm{Ca}^{2+}$ sensors. These components have specific distributions and roles within the cell, contributing to the maintenance of intracellular $\mathrm{Ca}^{2+}$ homeostasis [102]. The efflux of potassium $\left(\mathrm{K}^{+}\right)$ions through specific channels, instead, mediates the repolarization of membrane potential following depolarization. Increasing evidence indicates that the progressive $A \beta$ overproduction and accumulation cause the dysregulation of ionic homeostasis. Indeed, it has been widely demonstrated that $A \beta$ accumulation causes the influx of $\mathrm{Ca}^{2+}$ from the extracellular space, leading to $\mathrm{Ca}^{2+}$ dyshomeostasis $[75,103]$. On the contrary, intracellular $\mathrm{Ca}^{2+}$ levels can modulate APP processing and $A \beta$ production as well as the formation of NFTs [104,105]. Importantly, the genes associated with the development of AD have also been found to modulate $\mathrm{Ca}^{2+}$ signaling. Nonetheless, many $\mathrm{K}^{+}$and $\mathrm{Na}^{+}$channels appeared downregulated in both $\mathrm{AD}$ patients and experimental models, suggesting their potential role in $\mathrm{AD}$ pathophysiology. Moreover, the activity of ion-motive ATPases was found to be impaired in AD brains $[106,107]$, thus contributing to the dyshomeostasis of $\mathrm{Na}^{+}$and $\mathrm{Ca}^{2+}$ by inducing membrane depolarization and the opening of voltage-sensitive channels. All these disrup- 
tions contribute to the activation of intracellular pathways, leading to neuronal dysfunction and death [108].

\section{Calcium Homeostasis}

Calcium ions $\left(\mathrm{Ca}^{2+}\right)$ regulate the function of various enzymes and proteins and play an important role as secondary messengers in signal transduction pathways, including cell survival, proliferation, differentiation and apoptosis [109]. $\mathrm{Ca}^{2+}$ is also involved in the regulation of multiple neuronal and astrocytic functions, such as neurotransmitter release, synaptic plasticity, membrane excitability, gene transcription, proliferation and cell death $[110,111]$. It binds calmodulin $(\mathrm{CaM})$, causing its conformation change and the activation of calcineurin ( $\mathrm{CaN}), \mathrm{Ca}^{2+} /$ calmodulin dependent protein kinase II (CaMKII) and IV (CamKIV). CaMKII plays a pivotal role in synaptic strengthening [112], whereas CaMKIV regulates the transcription of cAMP response element binding protein (CREB), which is implicated in memory formation [113]. $\mathrm{Ca}^{2+}$ also modulates the function of protein kinase C (PKC), thus regulating cell survival and cell division [109].

The concentration of cytoplasmic $\mathrm{Ca}^{2+}$ in resting condition is maintained at $\sim 100 \mathrm{nM}$, far below the endoplasmic reticulum (ER) $(100-800 \mu \mathrm{M})$ and the extracellular medium ( 1-2 $\mathrm{mM})$ [114], and can increase up to 1-3 $\mu \mathrm{M}$ upon cell stimulation. Indeed, $\mathrm{Ca}^{2+}$ can cross the cellular membrane and/or can be released from intracellular stores [109]. These levels are finely regulated in cellular compartments by a different array of receptors, calcium channels and calcium pumps (Figure 1).

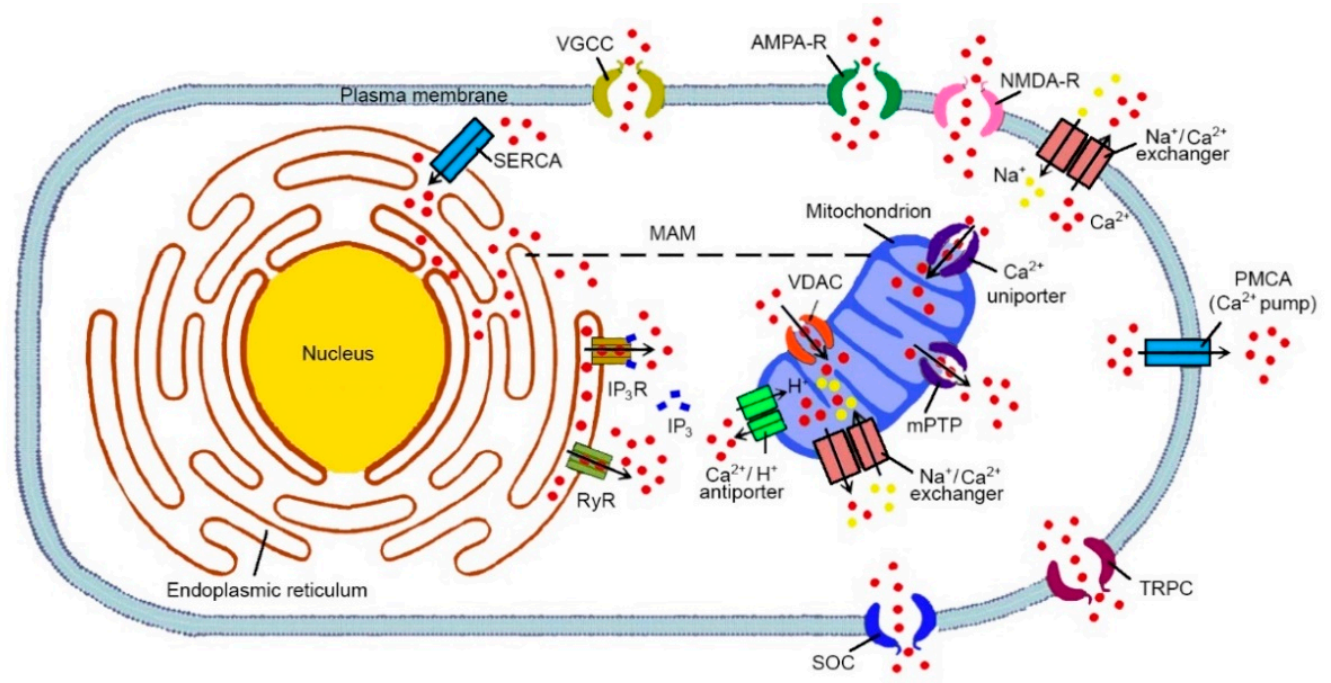

Figure 1. Calcium homeostasis in normal cells. Intracellular calcium $\left(\mathrm{Ca}^{2+}\right)$ levels are finely regulated within their physiological range (10-100 nM) against steep gradients by transport of the ion to the extracellular space and cisternae of the ER, and by protein binding. Cellular calcium influx through the plasma membrane is largely mediated by different types of $\mathrm{Ca}^{2+}$ channels (NMDA-R, AMPA-R, VGCC, SOC and TRPC channels) and, under exceptional circumstances, including strong depolarization or the presence of high intracellular sodium $\left(\mathrm{Na}^{+}\right)$concentrations, the $\mathrm{Na}^{+} / \mathrm{Ca}^{2+}$ exchanger. $\mathrm{Ca}^{2+}$ may also be released into the cytoplasm from the ER, through $\mathrm{IP}_{3} \mathrm{R}$ and $\mathrm{RYR}$. Cytosolic $\mathrm{Ca}^{2+}$ increase is counterbalanced by different systems. In particular, the PMCA, $\mathrm{Na}^{+} / \mathrm{Ca}^{2+}$ exchangers, and SERCA restore physiological calcium levels. The excess of intracellular $\mathrm{Ca}^{2+}$ can also be taken up by mitochondria through mitochondrial $\mathrm{Ca}^{2+}$ uniporters and VDAC. $\mathrm{Ca}^{2+}$ can be also released back into the cytosol through the mitochondrial $\mathrm{Na}^{+} / \mathrm{Ca}^{2+}$ exchangers, which can also reverse its mode of operation, allowing the $\mathrm{Ca}^{2+}$ entry into the mitochondrial matrix, the $\mathrm{Ca}^{2+} / \mathrm{H}^{+}$ antiporter and MPTP.

A variety of $\mathrm{Ca}^{2+}$ channels are present in the plasma membrane with a different distribution, resulting in a fine regulation of its concentration between the intracellular and extracellular space. In particular, N-methyl-D-aspartate receptor (NMDA-R), $\alpha$-amino-3- 
hydroxy-5-methyl-4-isoxazolepropionic acid receptor (AMPA-R), voltage-gated calcium channel (VGCC) and transient receptor potential cation channels (TRPC) regulate the $\mathrm{Ca}^{2+}$ influx from the extracellular space through a variety of signaling mechanisms [115]. The other major source for intracellular $\mathrm{Ca}^{2+}$ comes from internal stores, mostly the ER. The flux of $\mathrm{Ca}^{2+}$ from the ER to the cytosol is regulated by two key intracellular $\mathrm{Ca}^{2+}$ releasing channels: the inositol 1, 4, 5-trisphosphate receptor $\left(\mathrm{IP}_{3} \mathrm{R}\right)[116]$ and the ryanodine receptor (RyR) [117].

The first mechanism is driven by the G-protein coupled receptors (GPCRs) that activate phospholipase $\mathrm{C}$ (PLC), thus mobilizing the secondary messenger $\mathrm{IP}_{3}$ and diacylglycerol (DAG). $\mathrm{IP}_{3}$ interacts with $\mathrm{IP}_{3} \mathrm{R}$ on ER, causing its opening and the release of $\mathrm{Ca}^{2+}$ from the lumen of the ER to the cytosol. Released cytosolic $\mathrm{Ca}^{2+}$ regulates, in a specific concentrationdependent manner, the $\mathrm{IP}_{3} \mathrm{R}$ opening and the activation of RyRs, causing a further release of $\mathrm{Ca}^{2+}$ from the ER (Figure 1) [118]. In addition, the $\mathrm{Ca}^{2+}$ depletion in the ER causes the activation of the store operated channel (SOC) pathway, which sequesters $\mathrm{Ca}^{2+}$ from the extracellular space [119]. Further, sarco-endoplasmic reticulum calcium transport ATPase (SERCA) pumps, which are located on the ER surface, take up the $\mathrm{Ca}^{2+}$ from the cytoplasm to the ER [120]. Resting $\mathrm{Ca}^{2+}$ concentrations were maintained via extrusion mechanisms that transport $\mathrm{Ca}^{2+}$ out of the cell or back into intracellular stores. Indeed, $\mathrm{Ca}^{2+}$ is extruded from the cell by the plasma membrane $\mathrm{Ca}^{2+}$ ATPase (PMCA) [121] and the $\mathrm{Na}^{+} / \mathrm{Ca}^{2+}$ exchanger (NCX) [122]. Mitochondria also play a key role in maintaining cytosolic $\mathrm{Ca}^{2+}$ homeostasis (Figure 1). Indeed, mitochondria can activate both $\mathrm{Ca}^{2+}$ uptake and release through the mitochondrial $\mathrm{Ca}^{2+}$ uniporter complex (MCUC) $[123,124]$, the $\mathrm{Ca}^{2+} / \mathrm{Na}^{+}$antiporter (NCLX) [125], the $\mathrm{Ca}^{2+} / \mathrm{H}^{+}$antiporter [126], the voltage-dependent anion selective channel protein (VDAC) and the mitochondrial permeability transition pore (mPTP) (Figure 1) [127]. Mitochondrial $\mathrm{Ca}^{2+}$ uptake and release mechanisms are finely equilibrated under resting conditions in order to maintain the matrix $\mathrm{Ca}^{2+}$ concentrations at levels similar to cytoplasmic ones. Mitochondria can rapidly take up $\mathrm{Ca}^{2+}$ only when microdomains of high $\mathrm{Ca}^{2+}$ concentrations occur close to their surface. These $\mathrm{Ca}^{2+}$ microdomains are typically formed near the mitochondrial $\mathrm{Ca}^{2+}$ channels and receptors. Furthermore, the mitochondria in close proximity to the $\mathrm{Ca}^{2+}$ channels of the plasma membrane or the ER are able to rapidly take up $\mathrm{Ca}^{2+}$ during cytosolic $\mathrm{Ca}^{2+}$ rises [128]. The sites of proximity between the ER and mitochondria constitute specific subcellular regions, called mitochondria-associated ER membrane (MAM) [129]. MAM is a subdomain of the ER that provides a contact site between mitochondria and the ER (Figure 1), and is especially rich in cholesterol and sphingomyelin, thus mimicking the features of lipid rafts [130]. It is involved in various cellular functions, including $\mathrm{Ca}^{2+}$ transport, the synthesis of phospholipids, mitochondrial fission and fusion, the division of mtDNA, and cholesterol esterification [131]. The increase in intra-mitochondrial $\left[\mathrm{Ca}^{2+}\right]$ is slow and small for mitochondria that are distant from the microdomains. The alteration of MAMs has been linked to pathological conditions, such as cancer, neurodegenerative diseases, and metabolic syndromes [132].

\section{Calcium Dyshomeostasis in Alzheimer's Disease}

The so-called "Calcium hypothesis" was first postulated by Khachaturian in 1989 [133] following important experimental studies by the group of $[134,135]$. It explored how the activation of the amyloidogenic pathway may remodel the neuronal $\mathrm{Ca}^{2+}$ signaling pathways responsible for cognition. According to this hypothesis, the depolarization of aged neurons causes the influx of $\mathrm{Ca}^{2+}$ from the extracellular space and excitotoxicity. Other studies instead demonstrated that neuronal aging is associated with the alteration of neuronal $\mathrm{Ca}^{2+}$ extrusion, leading to old neurons being more vulnerable [136-138]. In particular, $\mathrm{Ca}^{2+}$ dyshomeostasis has been reported in both peripheral and central neurons during the aging process $[136,138]$ as well as in neurons of AD patients [139,140], influencing both A $\beta$ production and Tau hyperphosphorylation [141,142] (Figure 2). 
Indeed, several studies performed on both $\mathrm{AD}$ brains and experimental models showed that the alteration of $\mathrm{Ca}^{2+}$ homeostasis occurs before the development of the symptoms, suggesting that $\mathrm{Ca}^{2+}$ dysregulation is an upstream event in $\mathrm{AD}$ pathogenesis [143]. In addition, the calcium overload was coupled to the deposition of senile plaques and was most pronounced in the immediate vicinity of senile plaques in transgenic mouse models $[144,145]$. In particular, increased cytosolic $\mathrm{Ca}^{2+}$ levels can promote $\mathrm{A} \beta$ production and its following neurotoxicity, while the accumulation of the $\mathrm{A} \beta$ peptide results in the stimulation of neuronal $\mathrm{Ca}^{2+}$ signaling [101]. Therefore, a synergic mechanism between $\mathrm{Ca}^{2+}$ and $A \beta$ could intensify the neurodegeneration and cognitive deficits in AD patients [146].

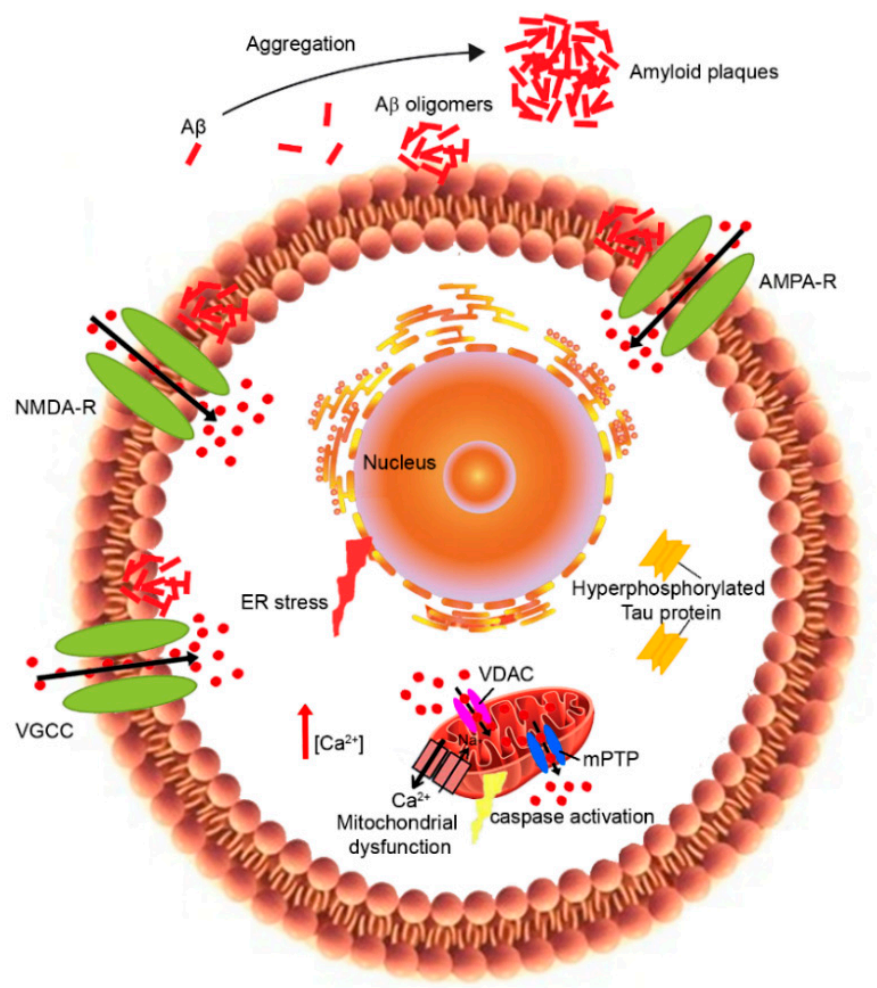

Figure 2. Effects of $A \beta$ and hyperphosphorylated tau protein on $\mathrm{Ca}^{2+}$ dysregulation and neuronal dysfunction in $\mathrm{AD}$ pathogenesis. $\mathrm{A} \beta$ oligomers formed in the extracellular space are able to interact with the plasma membrane, causing the hyperactivation of the calcium channels (NMDAR, AMPAR and VGCC). On the other hand, the intracellular hyperphosphorylated tau protein may promote $\mathrm{Ca}^{2+}$ dyshomeostasis. Overall, the increase in cytosolic $\mathrm{Ca}^{2+}$ levels results in mitochondrial dysfunction and the subsequent activation of the apoptotic cell death and ER stress.

\subsection{Plasma Membrane Calcium Dysregulation}

The ability of aberrant protein oligomers to penetrate and disrupt the cellular membrane and induce toxicity appears to result from direct interactions with the lipid bilayers $[75,76,147-149]$. Trodusquemine, a natural product in the aminosterol class, was recently shown to enhance the rate of $A \beta$ aggregation, thus reducing the lifetime or number of toxic oligomeric species. In addition, trodusquemine functions at phisiological concentration to prevent $A \beta$ toxicity by displacyng the aggregates from the cell membranes $[148,149]$. These studies provide confidence that aminosterols could be useful in the treatment of AD. Our previous analysis has shown the existence of a linear correlation between the rate of $\mathrm{Ca}^{2+}$ influx across plasma membranes and the amount of oligomeric species bound to the neuronal surface (Figure 3) [77]. These findings indicate that the susceptibility of neuronal cells to different types of misfolded oligomers is directly related to the extent of the binding of such oligomers to the cellular membrane. The ability of cell membranes to bind oligomeric aggregates appears to depend in turn on the physicochemical properties of 
both the oligomers and the membranes, which for the latter are determined in large part by their lipid composition $[147,150,151]$. In particular, the monosialotetrahexosylganglioside GM1 has been found to be an important factor in the context of AD [77,152,153]. GM1, together with cholesterol and sphingomyelin, is abundant in lipid raft domains within the cell membrane that contain a vast array of membrane proteins, including channels and receptors [154].

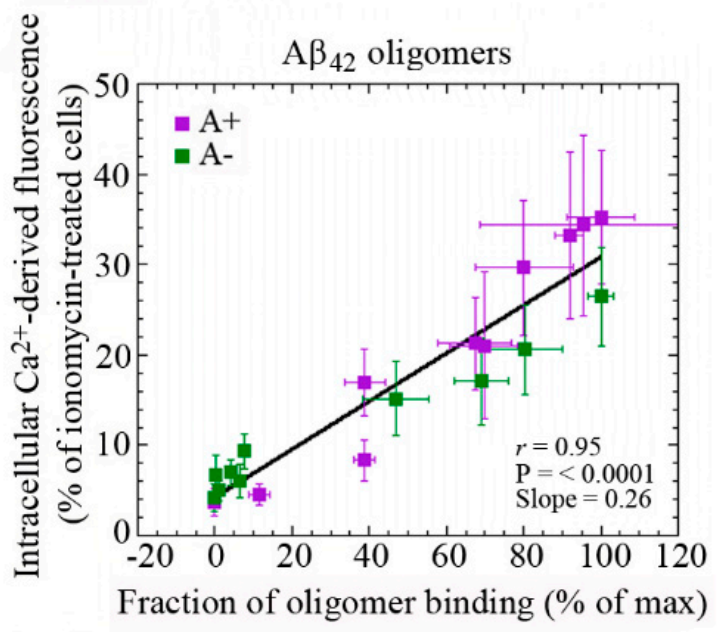

Figure 3. Dependence of intracellular $\mathrm{Ca}^{2+}$ dyshomeostasis on the binding affinities of $\mathrm{A} \beta 42$ oligomers to cellular membranes with different GM1 content. Changes in the intracellular $\mathrm{Ca}^{2+}$ levels plotted against the fraction of oligomer binding to the plasma membrane in GM1-modulated SH-SY5Y neuroblastoma cells treated for $1 \mathrm{~h}$ with $10 \mu \mathrm{M}$ A+ (violet) or A- (green) oligomers of A $\beta 42$ formed according to Ladiwala's protocol [151]. Reprinted from Figure 3B, Evangelisti et al., 2016, licensed under Creative Commons Attribution 4.0 International Public License (CC BY 4.0; https:/ / creativecommons.org/licenses/by/4.0/ (accessed on 5 May 2021)) [77].

There is strong evidence of a key role for $\mathrm{PrPc}$, a protein that is associated with lipid rafts, as a receptor for oligomers of the $\mathrm{A} \beta$ peptide, resulting in the activation of a Fynmediated complex signaling cascade leading to tau phosphorylation and $\mathrm{Ca}^{2+}$ dyshomeostasis [155]. Several studies support the idea that oligomers can interact with membranes through direct binding to GM1 $[156,157]$. This then results in the disruption of lipid bilayers, the alteration of their permeability and the malfunction of raft-associated $\mathrm{Ca}^{2+}$ channels, leading to $\mathrm{Ca}^{2+}$ influx into cells.

Although there is a variety of experiential evidence, the amyloid channel hypothesis still remains controversial. Indeed, numerous mechanisms can be responsible for the $\mathrm{A} \beta$ interaction with neuronal membranes causing the disruption of $\mathrm{Ca}^{2+}$ homeostasis. These include the activation of some type of cell surface receptor coupled to $\mathrm{Ca}^{2+}$ influx, and the alteration of membrane permeability $[147,158]$. Several reports showed that alterations in $\mathrm{Ca}^{2+}$ levels cause the dysfunction of VGCCs [138], the downregulation of $\mathrm{Ca}^{2+}$ clearance mechanisms at the plasma membrane level $[136,138]$ and the failure of $\mathrm{Ca}^{2+}$ homeostatic machinery located on intracellular organelles $[137,138]$. These events affected the maintenance of $\mathrm{Ca}^{2+}$ signals in old neurons, impairing learning and memory. It has been shown that $\mathrm{A} \beta$ can stimulate the opening of VGCCs, which, in turn, increases the intracellular concentration of $\mathrm{Ca}^{2+}$ [159]. In addition, the increase in intracellular $\mathrm{Ca}^{2+}$ levels can stimulate the overexpression of Ltype calcium channel subtype (Cav 1.2) in the hippocampal cell membranes of AD models, causing the influx of $\mathrm{Ca}^{2+}[160]$. The inhibition of SERCA as well as the release of $\mathrm{Ca}^{2+}$ via the RyR caused the increase in cytoplasmic $\mathrm{Ca}^{2+}$. This overloading caused the activation of $\beta$-secretase and thus an increased $A \beta$ production and aggregation [115].

In the past few years, in vitro studies demonstrated that the $A \beta$ peptide formed cationselective pores into the plasma membrane, thus causing $\mathrm{Ca}^{2+}$ influx from the extracellular 
space across these A $\beta$ pore-channels [161-164]. However, other in vivo studies showed that $A \beta$ can improve the plasma membrane permeability to both anions and cations by altering its dielectric structure [165]. Following this evidence, numerous researchers have focused their attention on the effects of $A \beta$ peptides on $\mathrm{Ca}^{2+}$ channels in neuronal cells. In particular, blocking $\mathrm{Ca}^{2+}$ influx was found to reduce the neurotoxicity of $\mathrm{A} \beta$ oligomers and the levels of insoluble $A \beta 1-40$ and $A \beta 1-42$ in the hippocampus of $A D$ transgenic mice [166]. The increase in intracellular $\mathrm{Ca}^{2+}$ promotes the activation of $\mathrm{CaN}$ and that of the phosphatases, including PP1, which is involved in long-term depression (LTD) [167]. $\mathrm{CaN}$ can contribute together with $\mathrm{A} \beta$ or tau to the loss of dendritic spines and synapses, leading to cognitive deficit in $\mathrm{AD}$ mouse models. Accordingly, $\mathrm{CaN}$ inhibitors can reverse or improve these impairments $[168,169]$. The $\mathrm{Ca}^{2+} / \mathrm{CaM}$ complex activates the CaMKII, playing an important role in memory formation and synaptic plasticity. Taking into account that many kinases can be activated by $\mathrm{Ca}^{2+}$, the dyshomeostasis of $\mathrm{Ca}^{2+}$ can increase tau phosphorylation [170-172]. Conversely, abnormal accumulation of intracellular tau can also induce $\mathrm{Ca}^{2+}$ overload, causing the dephosphorylation of CaMKIV and CREB by activating $\mathrm{CaN}$ [168]. The increase in cytosolic $\mathrm{Ca}^{2+}$ can also activate JAK2-STAT1 signaling, leading to the binding of STAT1 to NMDARs, and thus inhibits the transcription of specific GAS elements [170]; the increase in the cleaved STAT1 induced by tau also activates BACE1, promoting A $\beta$ production [173]. All of these alterations reveal new mechanisms by which tau can induce synapse impairments and cognitive deficits. PS1 and PS2 have also been implicated in the influx of $\mathrm{Ca}^{2+}$, as well as in the ER and mitochondrial $\mathrm{Ca}^{2+}$ signaling. Indeed, mutations in these proteins affect $\mathrm{Ca}^{2+}$ homeostasis [174].

An altered expression of calcium-binding (CBP) and calcium sensing proteins can modify the calcium-buffering capacity, causing the oversensitivity of neurons to glutamate released in the extracellular space [175-177]. In addition, the impairment of glutamate transporter function in the glial cell leads to the accumulation of glutamate in the synaptic cleft, activating the postsynaptic AMPA/NMDA receptors. Thus, $\mathrm{Ca}^{2+}$ entry in postsynaptic neurons disrupts the intracellular homeostasis and induces an increase in ROS production. A $\beta$ has been reported to bind to NMDA and AMPA glutamate receptors [178], as well as nicotinic acetylcholine receptors [179], and all of these receptors are highly $\mathrm{Ca}^{2+}$-permeable. Furthermore, $A \beta$ can influence VGCCs and $\mathrm{IP}_{3} \mathrm{R}$ [144]. Numerous research studies demonstrated that $A \beta$ promotes the upregulation of VGCCs in different neuronal types, including cortical and hippocampal neurons [180]. In particular, A $\beta$ peptides may over-activate the function of L-type VGCCs through a mechanism involving ROS production [181], or induce the overexpression of CaV1.2 and CaV1.3 channels in the hippocampus of $\mathrm{AD}$ transgenic mice [182] and in rat hippocampal neurons treated with $A \beta$ [183]. The effects of $A \beta$ on NMDARs have attracted considerable interest as these ligand-gated channels are involved in synaptic plasticity and LTP [184]. Indeed, $A \beta$ oligomers can induce the overactivation of NMDARs, resulting in a cytosolic $\mathrm{Ca}^{2+}$ increase $[77,137,153,185,186]$ through several mechanisms: by affecting glutamate availability $[187,188]$ and/or by modifying NMDAR electrophysiological properties [189], or by changing membrane tension [190]. Importantly, the overactivation of GluN2B NMDAR subunits induced by $A \beta$ [191] has been correlated to ER stress, to the depolarization and dysfunction of mitochondria [192,193], to microtubule disassembly and to a reduction in neurite length [191]. The synaptic activation of NMDAR is crucial for memory formation [194]. Hippocampal neurons showed differential expression of NMDA receptor subunits (NR1, NR2B) in AD-like rats [195]. In particular, the NR2B subunit, which is highly selective for $\mathrm{Ca}^{2+}$ transport and is known to play a decisive role in $\mathrm{Ca}^{2+}$-induced apoptosis, was overexpressed in AD models compared to controls [195]. The persistent overactivation of the NMDA receptor in the postsynaptic terminal stimulates hippocampal neurons, which allows higher calcium influx resulting in excitotoxicity. The $A \beta$-induced activation of NMDAR promoted its endocytosis [196]. We have recently observed that lysophosphatidylcholine and arachidonic acid, which cause membrane compression and stretch, respectively, can activate NMDAR and AMPAR through a change in membrane 
tension induced by A $\beta$ oligomers [190]. In particular, lysophosphatidylcholine is able to neutralize the oligomer-induced activation of the NMDA receptors, whereas arachidonic acid activates the receptors similarly to the oligomers with no additive effects, suggesting that $A \beta$-induced toxicity can also be caused by the perturbation of the mechanical properties of lipid membranes sensed by NMDA and AMPA receptors [190]. Memantine, an NMDAR antagonist, was approved in 2002 as a therapeutic drug in moderate to severe AD [197,198]. However, other potential drugs targeting NMDARs are not included in AD therapy because of their intolerable side effects.

\subsection{Endoplasmic-Reticulum Calcium Dysregulation}

As reported above, $A \beta$ peptides are able to induce a high release of $\mathrm{Ca}^{2+}$ from the ER, thus promoting the activation of the unfolded protein response (UPR) and ER stress $[199,200]$. Notably, A $\beta$ oligomers may disrupt ER Ca ${ }^{2+}$ homeostasis indirectly by the increase in $\mathrm{Ca}^{2+}$ influx from the extracellular space, which in turn triggers $\mathrm{Ca}^{2+}$ release from intracellular stores [201], or directly by interacting with several regulators of ER $\mathrm{Ca}^{2+}$, such as RyR and I $\mathrm{I}_{3}$ R [202-207]. On the other hand, ER Ca ${ }^{2+}$ dyshomeostasis causes abnormal $A \beta$ production and neuronal apoptosis [208-210]. In addition, $\mathrm{IP}_{3} \mathrm{R}$ was found to modulate $\mathrm{Ca}^{2+}$ homeostasis in $\mathrm{AD}[105]$ and its alterations have been detected in cells derived from AD patients since 1994 [211,212].

\subsection{Mitochondrial Calcium Dyshomeostasis}

Mitochondria play a key role in the modulation of intracellular $\mathrm{Ca}^{2+}$ signaling [213]. Indeed, they can quickly resume $\mathrm{Ca}^{2+}$ to prevent $\mathrm{Ca}^{2+}$ overload into the cytosol, activating the $\mathrm{Ca}^{2+}$-dependent mitochondrial matrix dehydrogenase to produce ATP. However, this disruption of mitochondrial $\mathrm{Ca}^{2+}$ regulation affects energy production and oxidative stress, resulting in mitochondrial dysfunction [214]. In particular, the excessive $\mathrm{Ca}^{2+}$ influx into the mitochondria induces mitochondrial outer membrane permeabilization and the subsequent release of pro-apoptotic factors into the cytoplasm, including cytochrome $\mathrm{C}$ and apoptosis-inducing factor, which activate apoptosis cell death [215] (Figure 2). Mitochondrial dysfunction has been proposed as an early event in AD and other aging-related neurodegenerative disorders [216]. Studies on brains from AD patients and AD mouse models showed impaired mitochondrial function, associated with decreased bioenergetics and ATP synthesis [217], morphological abnormalities [218], the imbalance of mitochondrial dynamics [219] and the redistribution of mitochondria [220]. Synapses are particularly rich in mitochondria, which provide energy for $\mathrm{Ca}^{2+}$ homeostasis. In addition, synaptic mitochondria are more sensitive to $\mathrm{Ca}^{2+}$ dyshomeostasis with respect to non-synaptic mitochondria [221]. During LTP, microtubule associated protein 1B (MAP1B) phosphorylation and local concentrations of CaMKII were increased [222]. CaMKII is responsible for phosphorylating MAP2, which enhances synaptic response [223]. The accumulation of tau impairs synapses and memory by activating $\mathrm{Ca}^{2+}$-dependent $\mathrm{CaN}$ and suppressing nuclear CaMKIV/CREB signaling, thus revealing a new mechanism by which tau can induce synaptic toxicity [168]. In vitro studies have reported that $A \beta$ oligomers induce mitochondrial $\mathrm{Ca}^{2+}$ uptake $[224,225]$ and $\mathrm{Ca}^{2+}$ transfer from the ER to mitochondria [226] in cultured rat primary neurons, even if the in vivo mechanism remains unknown. A recent study showed that the increase in $\mathrm{Ca}^{2+}$ levels in neuronal mitochondria of transgenic mice appeared only after plaque deposition and before neural death [227]. This mitochondrial $\mathrm{Ca}^{2+}$ overload involves toxic extracellular $\mathrm{A} \beta$ oligomers and requires the mitochondrial $\mathrm{Ca}^{2+}$ uniporter. The authors propose a novel potential therapeutic target for $\mathrm{AD}$ through the blocking of the mitochondrial $\mathrm{Ca}^{2+}$ uniporter that was found to reduce mitochondrial $\mathrm{Ca}^{2+}$ overload [227].

Various studies have observed that the increase in $\mathrm{Ca}^{2+}$ levels in the ER caused the leakage of $\mathrm{Ca}^{2+}$ into the cytoplasmic compartment, affecting the mitochondrial calcium homeostasis [140,228]. Recently, an interesting hypothesis has been proposed about the role of MAM, the lipid raft-like domain of the ER closely opposed to mitochondria (Figure 1), 
in AD pathogenesis [229]. As already mentioned, MAM is involved in several important mechanisms, including calcium transport, the synthesis of phospholipids, mitochondrial fission and fusion, the division of mtDNA, and cholesterol esterification [131]. Thus, several studies have been investigating the role of mitochondrial dysfunction mediated by $\mathrm{A} \beta$ and $\mathrm{MAM}$, underlying its putative role in AD.

\section{Concluding Remarks}

Many studies have revealed that the perturbation of $\mathrm{Ca}^{2+}$ homeostasis is an early event in the cascade of neuronal alterations underlying the cytotoxicity induced by misfolded $A \beta$ aggregates and hyperphosphorylated tau. However, so far, no common consensus has been reached on the molecular mechanisms of neuronal $\mathrm{Ca}^{2+}$ overload, causing the remodeling of signaling pathways with excitotoxicity and memory dysfunction in AD. The effects of $A \beta$ on NMDARs have attracted considerable interest as these ligand-gated channels are involved in synaptic plasticity and LTP. Importantly, the over-activation of GluN2B NMDAR subunits induced by $A \beta$ has been correlated to ER stress and to the depolarization and dysfunction of mitochondria. Recently, ER and mitochondrial $\mathrm{Ca}^{2+}$ dyshomeostasis have also been proposed as early causative events in AD.

The main unsolved issue is whether the neuronal $\mathrm{Ca}^{2+}$ alterations caused by $\mathrm{A} \beta$ extracellular deposits could be non-specific, involving just lipid membrane components, or specific by membrane receptors and other cell surface proteins. There is strong evidence of a key role for $\mathrm{PrPc}$, associated with lipid rafts, as a receptor for $\mathrm{A} \beta$ oligomers, resulting in the activation of a Fyn-mediated complex signaling cascade, leading to tau phosphorylation and loss of $\mathrm{Ca}^{2+}$ homeostasis. However, the data reported in several other studies support the idea that $A \beta$ oligomers can interact with membranes through direct binding to GM1. This then results in the disruption of lipid bilayers, the alteration of their permeability and the misfunction of raft-associated $\mathrm{Ca}^{2+}$ channels, leading to $\mathrm{Ca}^{2+}$ influx into cells. These findings do not necessarily contradict the view that PrPc behaves as a receptor of a class of $A \beta$ oligomers. Considering the existence of many structurally distinct conformers, different $A \beta$ aggregates could interact with PrPc and GM1 with different affinities. It is increasingly evident that toxicity is not a feature that is inherent to a given type of misfolded protein oligomer, but is instead a property that emerges from the complex interplay between the structural features of oligomers and the lipid composition of the neuronal membranes. Trodusquemine, a natural product in the aminosterol class, was recently shown to prevent $A \beta$ toxicity by displacyng the aggregates from the cell membranes, suggesting that molecules that interact directly with cell membranes, rather than binding oligomeric aggregate themselves, could represent a useful approach in the treatment of AD.

Overall, the question of the molecular basis of $\mathrm{Ca}^{2+}$ perturbation in $\mathrm{AD}$ pathophysiology needs further investigations for the development of targeted therapies for AD. Memantine, an NMDAR antagonist approved in 2002 as a therapeutic drug in moderate to severe $\mathrm{AD}$, appears to be promising in $\mathrm{AD}$ therapy, together with other potential drugs targeting NMDARs and PrPc. However, according to the latest evidence that both $A \beta$ and tau pathologies have synergistic effects, the most efficacious approach to slow AD may be to combine anti-A $\beta$ and anti-tau therapies.

Author Contributions: Writing, reviewing, and editing, R.C. and C.C.; conceptualization and supervision, R.C. and C.C.; both authors have read and agreed to the published version of the manuscript.

Funding: This research was funded by the University of Florence (Fondi Ateneo) and by the Ministry of Education, Universities and Research of Italy (Progetto Dipartimento di Eccellenza "Gender Medicine").

Conflicts of Interest: The authors declare no conflict of interest. 


\section{References}

1. Brookmeyer, R.; Johnson, E.; Ziegler-Graham, K.; Arrighi, H.M. Forecasting the global burden of Alzheimer's disease. Alzheimers Dement. 2007, 3, 186-191. [CrossRef] [PubMed]

2. Alzheimer's Association. 2016 Alzheimer's disease facts and figures. Alzheimers Dement. 2016, 12, 459-509. [CrossRef] [PubMed]

3. Elahi, F.M.; Miller, B.L. A clinicopathological approach to the diagnosis of dementia. Nat. Rev. Neurol. 2017, 13, 457-476. [CrossRef]

4. Cacabelos, R. Donepezil in Alzheimer's disease: From conventional trials to pharmacogenetics. Neuropsychiatr. Dis. Treat. 2007, 3, 303-333. [PubMed]

5. $\quad$ Birks, J.S.; Chong, L.Y.; Grimley Evans, J. Rivastigmine for Alzheimer's disease. Cochrane Database Syst. Rev. 2015, 9, CD001191. [PubMed]

6. Olin, J.T.; Schneider, L. Galantamine for Alzheimer's disease. Cochrane Database Syst. Rev. 2002. [CrossRef]

7. Alzheimer's Association. 2018 Alzheimer's disease facts and figures. Alzheimers Dement. 2018, 14, 367-429. [CrossRef]

8. Hampel, H.; Vergallo, A.; Afshar, M.; Akman-Anderson, L.; Arenas, J.; Benda, N.; Batrla, R.; Broich, K.; Caraci, F.; Cuello, A.C.; et al. Blood-based systems biology biomarkers for next-generation clinical trials in Alzheimer's disease. Dialogues Clin. Neurosci. 2019, 21, 177-191. [PubMed]

9. Scheltens, P.; Blennow, K.; Breteler, M.M.; de Strooper, B.; Frisoni, G.B.; Salloway, S.; Van de Flier, W.M. Alzheimer's disease. Lancet 2016, 388, 505-517. [CrossRef]

10. Selkoe, D.J.; Hardy, J. The amyloid hypothesis of Alzheimer's disease at 25 years. EMBO Mol. Med. 2016, 8, 595-608. [CrossRef]

11. Grundke-Iqbal, I.; Iqbal, K.; Tung, Y.C.; Wisniewski, H.M. Alzheimer paired helical filaments: Immunochemical identification of polypeptides. Acta Neuropathol. 1984, 62, 259-267. [CrossRef] [PubMed]

12. Steinman, J.; Sun, H.S.; Feng, Z.P. Microvascular alterations in Alzheimer's disease. Front. Cell. Neurosci. $2021,14,618986$. [CrossRef]

13. He, N.; Jin, W.L.; Lok, K.H.; Wang, Y.; Yin, M.; Wang, Z.J. Amyloid- $\beta 1-42$ oligomer accelerates senescence in adult hippocampal neural stem/progenitor cells via formylpeptide receptor 2. Cell Death Dis. 2013, 4, e924. [CrossRef]

14. Olsson, B.; Lautner, R.; Andreasson, U.; Öhrfelt, A.; Portelius, E.; Bjerke, M.; Höltta, M.; Rosén, C.; Olsson, C.; Strobel, G.; et al. CSF and blood biomarkers for the diagnosis of Alzheimer's disease: A systematic review and meta-analysis. Lancet Neurol. 2016, 15, 673-684. [CrossRef]

15. Lista, S.; Hampel, H. Synaptic degeneration and neurogranin in the pathophysiology of Alzheimer's disease. Expert Rev. Neurother. 2017, 17, 47-57. [CrossRef] [PubMed]

16. Baldacci, F.; Lista, S.; Cavedo, E.; Bonuccelli, U.; Hampel, H. Diagnostic function of the neuroinflammatory biomarker YKL-40 in Alzheimer's disease and other neurodegenerative diseases. Expert Rev. Proteom. 2017, 14, 285-299. [CrossRef] [PubMed]

17. Heneka, M.T.; Carson, M.J.; El Khoury, J.; Landreth, G.E.; Brosseron, F.; Feinstein, D.L.; Jacobs, A.H.; Wyss-Coray, T.; Vitorica, J.; Ransohoff, R.M.; et al. Neuroinflammation in Alzheimer's disease. Lancet Neurol. 2015, 14, 388-405. [CrossRef]

18. Iturria-Medina, Y.; Sotero, R.C.; Toussaint, P.J.; Mateos-Pérez, J.M.; Evans, A.C. Early role of vascular dysregulation on late-onset Alzheimer's disease based on multifactorial data-driven analysis. Nat. Commun. 2016, 7, 11934. [CrossRef] [PubMed]

19. De la Monte, S.M.; Tong, M. Brain metabolic dysfunction at the core of Alzheimer's disease. Biochem. Pharmacol. 2014, 88, 548-559. [CrossRef] [PubMed]

20. Hardy, J.; Selkoe, D. The amyloid hypothesis of Alzheimer's disease: Progress and problems on the road to therapeutics. Science 2002, 297, 353-356. [CrossRef] [PubMed]

21. Watts, J.C.; Prusiner, S.B. $\beta$-Amyloid Prions and the Pathobiology of Alzheimer's Disease. Cold Spring Harb. Perspect. Biol. 2017, 8, a023507. [CrossRef] [PubMed]

22. Chartier-Harlin, M.; Crawford, F.; Houlden, H.; Warren, A.; Hughes, D.; Fidani, L.; Goate, A.; Rossor, M.; Roques, P.; Hardy, J.; et al. Early-onset Alzheimer's disease caused by mutations at codon 717 of the $\beta$-amyloid precursor protein gene. Nature 1991, 353, 844-846. [CrossRef]

23. Citron, M.; Oltersdorf, T.; Haass, C.; McConlogue, L.; Hung, A.Y.; Seubert, P.; Vigo-Pelfrey, C.; Lieberburg, I.; Selkoe, D.J. Mutation of the $\beta$-amyloid precursor protein in familial Alzheimer's disease increases $\beta$-protein production. Nature 1992, 360, 672-674. [CrossRef] [PubMed]

24. Sherrington, R.; Rogaev, E.; Liang, Y.; Rogaeva, E.A.; Levesque, G.; Ikeda, M.; Chi, H.; Lin, C.; Li, G.; Holman, K.; et al. Cloning of a gene bearing missense mutations in early-onset familial Alzheimer's disease. Nature 1995, 375, 754-760. [CrossRef] [PubMed]

25. Busche, M.A.; Hyman, B.T. Synergy between amyloid- $\beta$ and tau in Alzheimer's disease. Nat. Neurosci. 2020, $23,1183-1193$. [CrossRef] [PubMed]

26. Barber, R.C. The Genetics of Alzheimer's Disease. Scientifica 2012, 246210. [CrossRef]

27. Bateman, R.J.; Aisen, P.S.; De Strooper, B.; Fox, N.C.; Lemere, C.A.; Ringman, J.M.; Salloway, S.; Sperling, R.A.; Windisch, M.; Xiong, C. Autosomal-dominant Alzheimer's disease: A review and proposal for the prevention of Alzheimer's disease. Alzheimers Res. Ther. 2011, 3, 1-13. [CrossRef]

28. Liu, E.; Zhou, Q.; Xie, A.J.; Li, M.; Zhang, S.; Huang, H.; Liuyang, Z.; Wang, Y.; Liu, B.; Li, X.; et al. Enriched gestation activates the IGF pathway to evoke embryo-adult benefits to prevent Alzheimer's disease. Transl. Neurodegener. 2019, 8, 8. [CrossRef]

29. Lambert, J.C.; Amouyel, P. Genetics of Alzheimer's disease: New evidences for an old hypothesis? Curr. Opin. Genet. Dev. 2011, 21, 295-301. [CrossRef] 
30. Peila, R.; Rodriguez, B.L.; Launer, L.J. Type 2 diabetes, APOE gene, and the risk for dementia and related pathologies: The Honolulu-Asia Aging Study. Diabetes 2002, 51, 1256-1262. [CrossRef] [PubMed]

31. Guo, J.; Xu, C.; Ni, S.; Zhang, S.; Li, Q.; Zeng, P.; Pi, G.; Liu, E.; Sun, D.-S.; Liu, Y.; et al. Elevation of pS262-tau and Demethylated PP2A in retina occurs earlier than in Hippocampus during Hyperhomocysteinemia. J. Alzheimers Dis. 2019, 68, 367-381. [CrossRef]

32. Xu, Z.P.; Yang, S.L.; Zhao, S.; Zheng, C.H.; Li, H.H.; Zhang, Y.; Huang, R.X.; Li, M.Z.; Gao, Y.; Zhang, S.J.; et al. Biomarkers for early diagnostic of mild cognitive impairment in Type-2 diabetes patients: A multicentre, retrospective, Nested Case-Control Study. EBioMedicine 2016, 5, 105-113. [CrossRef]

33. Zhang, Y.; Xie, J.Z.; Xu, X.Y.; Hu, J.; Xu, T.; Jin, S.; Yang, S.J.; Wang, J.Z. Liraglutide ameliorates hyperhomocysteinemia-induced Alzheimer-like pathology and memory deficits in rats via multi-molecular targeting. Neurosci. Bull. 2019, 35, 724-734. [CrossRef] [PubMed]

34. Bu, G. Apolipoprotein E and its receptors in Alzheimer's disease: Pathways, pathogenesis and therapy. Nat. Rev. Neurosci. 2009, 10, 333-344. [CrossRef]

35. Piaceri, I.; Nacmias, B.; Sorbi, S. Genetics of familial and sporadic Alzheimer's disease. Front. Biosci. (Elite Ed) $2013,5,167-177$. [CrossRef] [PubMed]

36. Thinakaran, G.; Koo, E.H. Amyloid precursor protein trafficking, processing, and function. J. Biol. Chem. 2008, 283, 29615-29619. [CrossRef] [PubMed]

37. LaFerla, F.M.; Green, K.N.; Oddo, S. Intracellular amyloid- $\beta$ in Alzheimer's disease. Nat. Rev. Neurosci. 2007, 8, 499-509. [CrossRef]

38. Tomita, T. Molecular mechanism of intramembrane proteolysis by $\gamma$-secretase. J. Biochem. 2014, 156, 195-201. [CrossRef] [PubMed]

39. Iwatsubo, T.; Odaka, A.; Suzuki, N.; Mizusawa, H.; Nukina, N.; Ihara, Y. Visualization of A $\beta 42(43)$ and A $\beta 40$ in senile plaques with end-specific $A \beta$ monoclonals: Evidence that an initially deposited species is A $\beta 42(43)$. Neuron 1994, 13, 45-53. [CrossRef]

40. Jonsson, T.; Atwal, J.; Steinberg, S.; Snaedal, J.; Jonsson, P.V.; Bjornsson, S.; Stefansson, H.; Sulem, P.; Gudbjartsson, D.; Maloney, J.; et al. A mutation in APP protects against Alzheimer's disease and age-related cognitive decline. Nature 2012, 488, 96-99. [CrossRef] [PubMed]

41. Li, Y.-M.; Xu, M.; Lai, M.-T.; Huang, Q.; Castro, J.L.; DiMuzio-Mower, J.; Harrison, T.; Lellis, C.; Nadin, A.; Neduvelil, J.G.; et al Photoactivated $\gamma$-secretase inhibitors directed to the active site covalently label presenilin 1. Nature 2000, 405, 689-694. [CrossRef]

42. Scheuner, D.; Eckman, C.; Jensen, M.; Song, X.; Citron, M.; Suzuki, N.; Bird, T.D.; Hardy, J.; Hutton, M.; Kukull, W.; et al. Secreted amyloid $\beta$-protein similar to that in the senile plaques of Alzheimer's diseaseis increased in vivo by the presenilin 1 and 2 and APP mutations linked to familial Alzheimer's disease. Nat. Med. 1996, 2, 864-870. [CrossRef]

43. Duff, K.; Eckman, C.; Zehr, C.; Yu, X.; Prada, C.M.; Perez-tur, J.; Hutton, M.; Buee, L.; Harigaya, Y.; Yager, D.; et al. Increased amyloid- $\beta 42(43)$ in brains of mice expressing mutant presenilin 1. Nature 1996, 383, 710-713. [CrossRef]

44. Borchelt, D.R.; Thinakaran, G.; Eckman, C.B.; Lee, M.K.; Davenport, F.; Ratovitsky, T.; Prada, C.M.; Kim, G.; Seekins, S.; Yager, D.; et al. Familial Alzheimer's disease-linked presenilin 1 variants elevate A $\beta 1-42 / 1-40$ ratio in vitro and in vivo. Neuron 1996, 17, 1005-1013. [CrossRef]

45. Kanatsu, K.; Morohashi, Y.; Suzuki, M.; Kuroda, H.; Watanabe, T.; Tomita, T.; Iwatsubo, T. Decreased CALM expression reduces $\mathrm{A} \beta 42$ to total $\mathrm{A} \beta$ ratio through clathrin-mediated endocytosis of $\gamma$-secretase. Nat. Commun. 2014, 5, 3386. [CrossRef] [PubMed]

46. Bitan, G.; Kirkitadze, M.D.; Lomakin, A.; Vollers, S.S.; Benedek, G.B.; Teplow, D.B. Amyloid beta-protein (Abeta) assembly: Abeta 40 and Abeta 42 oligomerize through distinct pathways. Proc. Natl. Acad. Sci. USA 2003, 100, 330-335. [CrossRef]

47. Haass, C.; Selkoe, D.J. Soluble protein oligomers in neurodegeneration: Lessons from the Alzheimer's amyloid beta-peptide. Nat. Rev. Mol. Cell Biol. 2007, 8, 101-112. [CrossRef] [PubMed]

48. Roychaudhuri, R.; Yang, M.; Hoshi, M.M.; Telow, D.B. Amyloid $\beta$-Protein Assembly and Alzheimer Disease. J. Biol. Chem. 2009, 284, 4749-4753. [CrossRef]

49. Gao, Y.; Tan, L.; Yu, J.T.; Tan, L. Tau in Alzheimer's disease: Mechanisms and therapeutic strategies. Curr. Alzheimer Res. 2018, 15, 283-300. [CrossRef] [PubMed]

50. Guo, T.; Noble, W.; Hanger, D.P. Roles of tau protein in health and disease. Acta Neuropathol. 2017, 133, 665-704. [CrossRef]

51. Alonso, A.; Zaidi, T.; Novak, M.; Grundke-Iqbal, I.; Iqbal, K. Hyperphosphorylation induces self-assembly of tau into tangles of paired helical filaments/straight filaments. Proc. Natl. Acad. Sci. USA 2001, 98, 6923-6928. [CrossRef] [PubMed]

52. Iqbal, K.; Liu, F.; Gong, C.X.; Grundke-Iqbal, I. Tau in Alzheimer disease and related tauopathies. Curr. Alzheimer Res. 2010, 7, 656-664. [CrossRef]

53. Jucker, M.; Walker, L.C. Propagation and spread of pathogenic protein assemblies in neurodegenerative diseases. Nat. Neurosci. 2018, 21, 1341-1349. [CrossRef]

54. Peng, C.; Trojanowski, J.Q.; Lee, V.M. Protein transmission in neurodegenerative disease. Nat. Rev. Neurol. 2020, 16, 199-212. [CrossRef] [PubMed]

55. Montine, T.J.; Phelps, C.H.; Beach, T.G.; Bigio, E.H.; Cairns, N.J.; Dickson, D.W.; Duyckaerts, C.; Frosch, M.P.; Masliah, E.; Mirra, S.S.; et al. National Institute on Aging-Alzheimer's Association guidelines for the neuropathologic assessment of Alzheimer's disease: A practical approach. Acta Neuropathol. 2012, 123, 1-11. [CrossRef] [PubMed]

56. Nelson, P.T.; Alafuzoff, I.; Bigio, E.H.; Bouras, C.; Braak, H.; Cairns, N.J.; Castellani, R.J.; Crain, B.J.; Davies, P.; del Tredici, K.; et al. Correlation of Alzheimer disease neuropathologic changes with cognitive status: A review of the literature. J. Neuropathol. Exp. Neurol. 2012, 71, 362-381. [CrossRef] 
57. Benilova, I.; Karran, E.; De Strooper, B. The toxic A $\beta$ oligomer and Alzheimer's disease: An emperor in need of clothes. Nat. Neurosci. 2012, 15, 349-357. [CrossRef]

58. Hardy, J.A.; Higgins, G.A. Alzheimer's disease: The amyloid cascade hypothesis. Science 1992, 256, 184-185. [CrossRef] [PubMed]

59. Hardy, J.; Allsop, D. Amyloid deposition as the central event in the aetiology of Alzheimer's disease. Trends Pharmacol. Sci. 1991, 12, 383-388. [CrossRef]

60. Selkoe, D.J. The molecular pathology of Alzheimer's disease. Neuron 1991, 6, 487-498. [CrossRef]

61. Braak, H.; Braak, E. Morphological criteria for the recognition of Alzheimer's disease and the distribution pattern of cortical changes related to this disorder. Neurobiol. Aging 1994, 15, 355-356. [CrossRef]

62. Masters, C.L.; Simms, G.; Weinman, N.A.; Multhaup, G.; Mcdonald, B.L.; Beyreuther, K. Amyloid plaque core protein in Alzheimer disease and down syndrome. Proc. Natl. Acad. Sci. USA 1985, 82, 4245-4249. [CrossRef]

63. Sowade, R.F.; Jahn, T.R. Seed-induced acceleration of amyloid-betamediated neurotoxicity in vivo. Nat. Commun. 2017, 8, 512. [CrossRef] [PubMed]

64. Hardy, J. Has the amyloid cascade hypothesis for Alzheimer's disease been proved? Curr. Alzheimer Res. 2006, 3, 71-73. [CrossRef] [PubMed]

65. Bryan, K.J.; Lee, H.; Perry, G.; Smith, M.A.; Casadesus, G. Transgenic mouse models of Alzheimer's disease: Behavioral testing and considerations. In Methods of Behavior Analysis in Neuroscience, 2nd ed.; Buccafusco, J.J., Ed.; CRC Press: Boca Raton, FL, USA, 2009.

66. Walsh, D.M.; Selkoe, D.J. Oligomers on the brain: The emerging role of soluble protein aggregates in neurodegeneration. Protein Pept. Lett. 2004, 11, 213-228. [CrossRef]

67. Selkoe, D.J. Biochemistry and molecular biology of amyloid $\beta$-protein and the mechanism of Alzheimer's disease. Handb. Clin. Neurol. 2008, 89, 245-260. [PubMed]

68. Irvine, G.B.; El-Agnaf, O.M.; Shankar, G.M.; Walsh, D.M. Protein aggregation in the brain: The molecular basis for Alzheimer's and Parkinson's diseases. Mol. Med. 2008, 14, 451-464. [CrossRef] [PubMed]

69. Busche, M.A.; Chen, X.; Henning, H.A.; Reichwald, J.; Staufenbiel, M.; Sakmann, B.; Konnerth, A. Critical role of soluble amyloid- $\beta$ for early hippocampal hyperactivity in a mouse model of Alzheimer's disease. Proc. Natl. Acad. Sci. USA 2012, 109, 8740-8745. [CrossRef] [PubMed]

70. Arbel-Ornath, M.; Hudry, E.; Boivin, J.R.; Hashimoto, T.; Takeda, S.; Kuchibhotla, K.V.; Hou, S.; Lattarulo, C.R.; Belcher, A.M.; Shakerdge, N.; et al. Soluble oligomeric amyloid- $\beta$ induces calcium dyshomeostasis that precedes synapse loss in the living mouse brain. Mol. Neurodegener. 2017, 12, 27. [CrossRef] [PubMed]

71. Ferreira, S.T.; Klein, W.L. The A $\beta$ oligomer hypothesis for synapse failure and memory loss in Alzheimer's disease. Neurobiol. Learn. Mem. 2011, 96, 529-543. [CrossRef] [PubMed]

72. Ferreira, I.L.; Ferreiro, E.; Schmidt, J.; Cardoso João, M.; Pereira, C.M.F.; Carvalho, A.L.; Oliveira, C.R.; Rego, A.C. A $\beta$ and NMDAR activation cause mitochondrial dysfunction involving ER calcium release. Neurobiol. Aging 2015, 36, 680-692. [CrossRef] [PubMed]

73. Friedrich, R.P.; Tepper, K.; Ronicke, R.; Soom, M.; Westermann, M.; Reymann, K.; Kaether, C.; Fandrich, M. Mechanism of amyloid plaque formation suggests an intracellular basis of Abeta pathogenicity. Proc. Natl. Acad. Sci. USA 2010, 107, 1942-1947. [CrossRef] [PubMed]

74. Kayed, R.; Lasagna-Reeves, C.A. Molecular Mechanism of amyloid Oligomers Toxicity. J. Alzheimers Dis. 2013, 33, S67-S78. [CrossRef] [PubMed]

75. Cecchi, C.; Stefani, M. The amyloid-cell membrane system. The interplay between the biophysical features of oligomers/fibrils and cell membrane defines amyloid toxicity. Biophys. Chem. 2013, 182, 30-43. [CrossRef] [PubMed]

76. Zampagni, M.; Evangelisti, E.; Cascella, R.; Liguri, G.; Becatti, M.; Pensalfini, A.; Uberti, D.; Cenini, G.; Memo, M.; Bagnoli, S.; et al Lipid rafts are primary mediators of amyloid oxidative attack on plasma membrane. J. Mol. Med. 2010, 88, 597-608. [CrossRef] [PubMed]

77. Evangelisti, E.; Cascella, R.; Becatti, M.; Marrazza, G.; Dobson, C.M.; Chiti, F.; Stefani, M.; Cecchi, C. Binding affinity of amyloid oligomers to cellular membranes is a generic indicator of cellular dysfunction in protein misfolding diseases. Sci. Rep. 2016, 6, 32721. [CrossRef] [PubMed]

78. Bigi, A.; Loffredo, G.; Cascella, R.; Cecchi, C. Targeting pathological amyloid aggregates with conformation-sensitive antibodies. Curr. Alzheimer Res. 2020, 17, 722-734. [CrossRef]

79. Cheignon, C.; Tomas, M.; Bonnefont-Rousselot, D.; Faller, P.; Hureau, C.; Collin, F. Oxidative stress and the amyloid beta peptide in Alzheimer's disease. Redox Biol. 2018, 14, 450-464. [CrossRef] [PubMed]

80. Cecchi, C.; Latorraca, S.; Sorbi, S.; Iantomasi, T.; Favilli, F.; Vincenzini, M.T.; Liguri, G. Glutathione level is altered in lymphoblasts from patients with familial Alzheimer's disease. Neurosci. Lett. 1999, 275, 152-154. [CrossRef]

81. Pensalfini, A.; Cecchi, C.; Zampagni, M.; Becatti, M.; Favilli, F.; Paoli, P.; Catarzi, S.; Bagnoli, S.; Nacmias, B.; Sorbi, S.; et al. Protective effect of new S-acylglutathione derivatives against amyloid-induced oxidative stress. Free Rad. Biol. Med. 2008, 44, 1624-1636. [CrossRef] [PubMed]

82. Pensalfini, A.; Zampagni, M.; Liguri, G.; Becatti, M.; Evangelisti, E.; Fiorillo, C.; Bagnoli, S.; Cellini, E.; Nacmias, B.; Sorbi, S.; et al. Membrane cholesterol enrichment prevents A $\beta$-induced oxidative stress in Alzheimer's fibroblasts. Neurobiol. Aging 2011, 32, 210-222. [CrossRef] [PubMed] 
83. Cenini, G.; Cecchi, C.; Pensalfini, A.; Bonini, S.A.; Ferrari-Toninelli, G.; Liguri, G.; Memo, M.; Uberti, D. Generation of reactive oxygen species by beta amyloid fibrils and oligomers involves different intra/extracellular pathways. Amino Acids 2010, 38, 1101-1106. [CrossRef] [PubMed]

84. Zampagni, M.; Wright, D.; Cascella, R.; D’Adamio, G.; Casamenti, F.; Evanglisti, E.; Cardona, F.; Goti, A.; Nacmias, B.; Sorbi, S.; et al. Novel S-acyl glutathione derivatives prevent amyloid oxidative stress and cholinergic dysfunction in Alzheimer disease models. Free Radic. Biol. Med. 2012, 52, 1362-1371. [CrossRef] [PubMed]

85. Cascella, R.; Evangelisti, E.; Zampagni, M.; Becatti, M.; D’Adamio, G.; Goti, A.; Liguri, G.; Fiorillo, C.; Cecchi, C. S-linolenoyl glutathione intake extends life-span and stress resistance via Sir-2.1 upregulation in Caenorhabditis elegans. Free Radic. Biol. Med. 2014, 73, 127-135. [CrossRef]

86. Jackson, M.P.; Hewitt, E.W. Cellular proteostasis: Degradation of misfolded proteins by lysosomes. Essay Biochem. 2016, 60, 173-180.

87. Höhn, A.; Tramutola, A.; Cascella, R. Proteostasis Failure in Neurodegenerative Diseases: Focus on Oxidative Stress. Oxid. Med. Cell. Longev. 2020, 5497046. [CrossRef]

88. Salminen, A.; Kaarniranta, K.; Hauppinen, A.; Ojala, J.; Haapasalo, A.; Soininen, H.; Hiltunen, M. Impaired autophagy and APP processing in Alzheimer's disease: The potential role of Beclin 1 interactome. Prog. Neurobiol. 2013, 106-107, 33-54. [CrossRef]

89. Crews, L.; Masliah, E. Molecular mechanisms of neurodegeneration in Alzheimer's disease. Hum. Mol. Genet. 2010, 19, R12-R20. [CrossRef]

90. Lobello, K.; Ryan, J.M.; Liu, E.; Rippon, G.; Black, R. Targeting Beta amyloid: A clinical review of immunotherapeutic approaches in Alzheimer's disease. Int. J. Alzheimers Dis. 2012, 2012, 628070. [CrossRef]

91. Cascella, R.; Conti, S.; Tatini, F.; Evangelisti, E.; Scartabelli, T.; Casamenti, F.; Wilson, M.R.; Chiti, F.; Cecchi, C. Extracellular chaperones prevent A 342 -induced toxicity in rat brains. Biochim. Biophys. Acta 2013, 1832, 1217-1226. [CrossRef]

92. Dourlen, P.; Kilinc, D.; Malmanche, N.; Chapuis, J.; Lambert, J.C. The new genetic landscape of Alzheimer's disease: From amyloid cascade to genetically driven synaptic failure hypothesis? Acta Neuropathol. 2019, 138, 221-236. [CrossRef]

93. Bennett, R.E.; DeVos, S.L.; Dujardin, S.; Corjuc, B.; Gor, R.; Gonzalez, J.; Roe, A.D.; Frosch, M.P.; Pitstick, R.; Carlson, G.A.; et al. Enhanced tau aggregation in the presence of amyloid $\beta$. Am. J. Pathol. 2017, 187, 1601-1612. [CrossRef]

94. Busche, M.A.; Wegmann, S.; Dujardin, S.; Commins, S.; Schiantarelli, J.; Klickstein, N.; Kamath, T.V.; Carlson, G.A.; Nelken, I.; Hyman, B.T. Tau impairs neural circuits, dominating amyloid- $\beta$ effects, in Alzheimer models in vivo. Nat. Neurosci. 2019, 22, 57-64. [CrossRef] [PubMed]

95. Takeda, S.; Wegmann, S.; Cho, H.; DeVos, S.L.; Commins, C.; Roe, A.D.; Nicholls, S.B.; Carlson, G.A.; Pitstick, R.; Nobuhara, C.K.; et al. Neuronal uptake and propagation of a rare phosphorylated high-molecular-weight tau derived from Alzheimer's disease brain. Nat. Commun. 2015, 6, 8490. [CrossRef]

96. Hanseeuw, B.J.; Betensky, R.A.; Jacob, H.I.L.; Schultz, A.P.; Sepulcre, J.; Becker, J.A.; Orozco Cosio, D.M.; Farrell, M.; Quiroz, Y.T.; Mormino, E.C.; et al. Association of amyloid and tau with cognition in preclinical Alzheimer disease: A longitudinal study. JAMA Neurol. 2019, 76, 915-924. [CrossRef]

97. Timmers, M.; Tesseur, I.; Bogert, J.; Zetterberg, H.; Blennow, K.; Börjesson-Hanson, A.; Baquero, M.; Boada, M.; Randolph, C.; Tritsmans, L.; et al. Relevance of the interplay between amyloid and tau for cognitive impairment in early Alzheimer's disease. Neurobiol. Aging 2019, 79, 131-141. [CrossRef] [PubMed]

98. Majdi, A.; Sadigh-Eteghad, S.; Aghsan, S.R.; Farajdokht, F.; Vatandoust, S.M.; Namvaran, A.; Mahmoudi, J. Amyloid- $\beta$, tau, and the cholinergic system in Alzheimer's disease: Seeking direction in a tangle of clues. Rev. Neurosci. 2020, 31, 391-413. [CrossRef] [PubMed]

99. Lynch, G.; Seubert, P. Links between long-term potentiation and neuropathology. An hypothesis involving calcium-activated proteases. Ann. N. Y. Acad. Sci. 1989, 568, 171-180. [CrossRef] [PubMed]

100. Briggs, C.A.; Chakroborty, S.; Stutzmann, G.E. Emerging pathways driving early synaptic pathology in Alzheimer's disease. Biochem. Biophys. Res. Commun. 2017, 19, 988-997. [CrossRef]

101. Pchitskaya, E.; Popugaeva, E.; Bezprozvanny, I. Calcium signaling and molecular mechanisms underlying neurodegenerative diseases. Cell Calcium 2018, 70, 87-94. [CrossRef] [PubMed]

102. Zampese, E.; Pizzo, P. Intracellular organelles in the saga of $\mathrm{Ca}^{2+}$ homeostasis: Different molecules for dierent purposes? Cell. Mol. Life Sci. 2012, 69, 1077-1104. [CrossRef]

103. Supnet, C.; Bezprozvanny, I. The dysregulation of intracellular calcium in Alzheimer disease. Cell Calcium 2010, 47, 183-189. [CrossRef]

104. LaFerla, F.M. Calcium dyshomeostasis and intracellular signalling in Alzheimer's disease. Nat. Rev. Neurosci. 2002 , 3, 862-872. [CrossRef] [PubMed]

105. Green, K.N.; LaFerla, F.M. Linking calcium to Abeta and Alzheimer's disease. Neuron 2008, 59, 190-194. [CrossRef]

106. Mark, R.J.; Hensley, K.; Butterfield, D.A.; Mattson, M.P. Amyloid beta-peptide impairs ion-motive ATPase activities: Evidence for a role in loss of neuronal $\mathrm{Ca}^{2+}$ homeostasis and cell death. J. Neurosci. 1995, 15, 6239-6249. [CrossRef] [PubMed]

107. Mark, R.J.; Keller, J.N.; Kruman, I.; Mattson, M.P. Basic FGF attenuates amyloid beta-peptide-induced oxidative stress, mitochondrial dysfunction, and impairment of $\mathrm{Na}+/ \mathrm{K}+$-ATPase activity in hippocampal neurons. Brain Res. 1997, 756, 205-214. [CrossRef] 
108. Santos, S.F.; Pierrot, N.; Octave, J.N. Network excitability dysfunction in Alzheimer's disease: Insights from in vitro and in vivo models. Rev. Neurosci. 2010, 21, 153-171.

109. Clapham, D.E. Calcium Signaling. Cell 2007, 131, 1047-1058. [CrossRef]

110. Berridge, M.J. Neuronal calcium signaling. Neuron 1998, 2, 13-26. [CrossRef]

111. Berridge, M.J.; Lipp, P.; Bootman, M.D. The versatility and universality of calcium signalling. Nat. Rev. Mol. Cell Biol. 2000, 1, 11-21. [CrossRef] [PubMed]

112. Lisman, J.; Schulman, H.; Cline, H. The molecular basis of CaMKII function in synaptic and behavioral memory. Nat. Rev. Neurosci. 2002, 3, 175-190. [CrossRef] [PubMed]

113. Kang, H.; Sun, L.D.; Atkins, C.M.; Soderling, T.R.; Wilson, M.A.; Tonegawa, S. An important role of neural activity-dependent CaMKIV signaling in the consolidation of long-term memory. Cell 2001, 106, 771-783. [CrossRef]

114. Burgoyne, R.D.; Helassa, N.; McCue, H.V.; Haynes, L.P. Calcium sensors in neuronal function and dysfunction. Cold Spring Harb. Perspect. Biol. 2019, 11, a035154. [CrossRef]

115. Wang, Y.; Shi, Y.; Wei, H. Calcium Dysregulation in Alzheimer's Disease: A Target for New Drug Development. J. Alzheimers Dis. Parkinsonism 2017, 7, 374. [CrossRef] [PubMed]

116. Prole, D.L.; Taylor, C.W. Structure and function of ip3 receptors. Cold Spring Harb. Perspect. Biol. 2019, 11, a035063. [CrossRef] [PubMed]

117. Santulli, G.; Nakashima, R.; Yuan, Q.; Marks, A.R. Intracellular calcium release channels: An update. J. Physiol. 2017, 595, 3041-3051. [CrossRef] [PubMed]

118. Krebs, J.; Agellon, L.B.; Michalak, M. Ca ${ }^{2+}$ homeostasis and endoplasmic reticulum (ER) stress: An integrated view of calcium signaling. Biochem. Biophys. Res. Commun. 2015, 460, 114-121. [CrossRef]

119. Putney, J.W.; Steinckwich-Besançon, N.; Numaga-Tomita, T.; Davis, F.M.; Desai, P.N.; D'Agostin, D.M.; Wu, S.; Bird, G.S. The functions of store-operated calcium channels. Biochim. Biophys. Acta Mol. Cell Res. 2017, 1864, 900-906. [CrossRef] [PubMed]

120. Prakriya, M.; Lewis, R.S. Store-operated calcium channels. Physiol. Rev. 2015, 95, 1383-1436. [CrossRef]

121. Staord, N.; Wilson, C.; Oceandy, D.; Neyses, L.; Cartwright, E.J. The plasma membrane calcium ATPases and their role as major new players in human disease. Physiol. Rev. 2017, 97, 1089-1125. [CrossRef] [PubMed]

122. DiPolo, R.; Beaugé, L. Sodium/calcium exchanger: Influence of metabolic regulation on ion carrier interactions. Physiol. Rev. 2006, 86, 155-203. [CrossRef]

123. Baughman, J.M.; Perocchi, F.; Girgis, H.S.; Plovanich, M.; Belcher-Timme, C.A.; Sancak, Y.; Bao, X.R.; Strittmatter, L.; Goldberger, O.; Bogorad, R.L.; et al. Integrative genomics identifies MCU as an essential component of the mitochondrial calcium uniporter. Nature 2011, 476, 341-345. [CrossRef] [PubMed]

124. De Stefani, D.; Raffaello, A.; Teardo, E.; Szabó, I.; Rizzuto, R. A forty-kilodalton protein of the inner membrane is the mitochondrial calcium uniporter. Nature 2011, 476, 336-340. [CrossRef] [PubMed]

125. Palty, R.; Silverman, W.F.; Hershfinkel, M.; Caporale, T.; Sensi, S.L.; Parnis, J.; Nolte, C.; Fishman, D.; Shoshan-Barmatz, V.; Herrmann, S.; et al. NCLX is an essential component of mitochondrial Na+/Ca2+ exchange. Proc. Natl. Acad. Sci. USA 2010, 107, 436-441. [CrossRef] [PubMed]

126. Jiang, D.; Zhao, L.; Clapham, D.E. Genome-wide RNAi screen identifies Letm1 as a mitochondrial Ca2+/H+ antiporter. Science 2009, 326, 144-147. [CrossRef] [PubMed]

127. Bronner, F. Extracellular and intracellular regulation of calcium homeostasis. Sci. World J. 2001, 1, 919-925. [CrossRef]

128. Rizzuto, R. Close Contacts with the Endoplasmic Reticulum as Determinants of Mitochondrial Ca ${ }^{2+}$ Responses. Science 1998, 280, 1763-1766. [CrossRef] [PubMed]

129. Vance, J.E. MAM (mitochondria-associated membranes) in mammalian cells: Lipids and beyond. Biochim. Biophys. Acta 2014, 1841, 4. [CrossRef] [PubMed]

130. Hayashi, T.; Su, T.P. Cholesterol at the endoplasmic reticulum: Roles of the sigma-1 receptor chaperone and implications thereof in human diseases. Subcell. Biochem. 2010, 51, 381-398.

131. Hayashi, T.; Rizzuto, R.; Hajnoczky, G.; Su, T.P. MAM: More than just a housekeeper. Trends Cell Biol. 2009, 19, 81-88. [CrossRef]

132. Pinton, P. Mitochondria-associated membranes (MAMs) and pathologies editorial. Cell Death Dis. 2018, 9, 413. [CrossRef] [PubMed]

133. Khachaturian, Z.S. Calcium, membranes, aging, and Alzheimer's disease. Introduction and overview. Ann. N. Y. Acad. Sci. 1989, 568, 1-4. [CrossRef]

134. Landfield, P.W.; Pitler, T.A. Prolonged Ca2+-dependent after hyperpolarizations in hippocampal neurons of aged rats. Science 1984, 226, 1-4. [CrossRef]

135. Landfield, P.W. Increased calcium current' hypothesis of brain aging. Neurobiol. Aging 1987, 8, 346-347. [CrossRef]

136. Verkhratsky, A.; Toescu, E.C. Calcium and neuronal ageing. Trends Neurosci. 1998, 21, 2-7. [CrossRef]

137. Toescu, E.C.; Verkhratsky, A.; Landfield, P.W. $\mathrm{Ca}^{2+}$ regulation and gene expression in normal brain aging. Trends Neurosci. 2004, 27, 614-620. [CrossRef]

138. Toescu, E.C.; Verkhratsky, A. The importance of being subtle: Small changes in calcium homeostasis control cognitive decline in normal aging. Aging Cell 2007, 6, 267-273. [CrossRef] [PubMed]

139. Foster, T.C. Calcium homeostasis and modulation of synaptic plasticity in the aged brain. Aging Cell 2007, 6, 319-325. [CrossRef] [PubMed] 
140. Bezprozvanny, I. Calcium signaling and neurodegenerative diseases. Trends Mol. Med. 2009, 15, 89-100. [CrossRef] [PubMed]

141. Querfurth, H.W.; Selkoe, D.J. Calcium ionophore increases amyloid $\beta$ peptide production by cultured cells. Biochemistry 1994, 33, 4550-4561. [CrossRef]

142. Bezprozvanny, I.; Mattson, M.P. Neuronal calcium mishandling and the pathogenesis of Alzheimer's disease. Trends Neurosci. 2008, 31, 454-463. [CrossRef]

143. Etcheberrigaray, R.; Hirashima, N.; Nee, L.; Prince, J.; Govoni, S.; Racchi, M.; Tanzi, R.D.; Alkon, L. Calcium responses in fibroblasts from asymptomatic members of Alzheimer's disease families. Neurobiol. Dis. 1998, 5, 37-45. [CrossRef] [PubMed]

144. Latulippe, J.; Lotito, D. A mathematical model for the effects of amyloid beta on intracellular calcium. PLoS ONE 2018, 13, e0202503. [CrossRef]

145. Kuchibhotla, K.V.; Goldman, S.T.; Lattarulo, C.R.; Wu, H.Y.; Hyman, B.T.; Bacskai, B.J. Abeta plaques lead to aberrant regulation of calcium homeostasis in vivo resulting in structural and functional disruption of neuronal networks. Neuron 2008, 59, 214-225. [CrossRef] [PubMed]

146. Demuro, A.; Mina, E.; Kayed, R.; Milton, S.C.; Parker, I.; Glabe, C.G. Calcium dysregulation and membrane disruption as a ubiquitous neurotoxic mechanism of soluble amyloid oligomers. J. Biol. Chem. 2005, 280, 17294-17300. [CrossRef] [PubMed]

147. Evangelisti, E.; Cecchi, C.; Cascella, R.; Sgromo, C.; Becatti, M.; Dobson, C.M.; Chiti, F.; Stefani, M. Membrane lipid composition and its physicochemical properties define cell vulnerability to aberrant protein oligomers. J. Cell Sci. 2012, 125, $2416-2427$. [CrossRef] [PubMed]

148. Limbocker, R.; Chia, S.; Ruggeri, F.S.; Perni, M.; Cascella, R.; Heller, G.T.; Meisl, G.; Mannini, B.; Habchi, J.; Michaels, T.C.T.; et al. Trodusquemine enhances $\mathrm{A} \beta 42$ aggregation but suppresses its toxicity by displacing oligomers from cell membranes. Nat. Commun. 2019, 10, 225. [CrossRef] [PubMed]

149. Limbocker, R.; Mannini, B.; Ruggeri, F.S.; Cascella, R.; Xu, C.K.; Perni, M.; Chia, S.; Chen, S.W.; Habchi, J.; Bigi, A.; et al. Trodusquemine displaces protein misfolded oligomers from cell membranes and abrogates their cytotoxicity through a generic mechanism. Commun. Biol. 2020, 3, 435. [CrossRef] [PubMed]

150. Evangelisti, E.; Wright, D.; Zampagni, M.; Cascella, R.; Fiorillo, C.; Bagnoli, S.; Relini, A.; Nichino, D.; Scartabelli, T.; Nacmias, B.; et al. Lipid rafts mediate amyloid-induced calcium dyshomeostasis and oxidative stress in Alzheimer's disease. Curr. Alzheimer Res. 2013, 10, 143-153. [CrossRef]

151. Ladiwala, A.R.; Litt, J.; Kane, R.S.; Aucoin, D.S.; Smith, S.O.; Ranjan, S.; Davis, J.; Van Nostrand, W.E.; Tessier, P.M. Conformational differences between two amyloid beta oligomers of similar size and dissimilar toxicity. J. Biol. Chem. 2012, 287, 24765-24773. [CrossRef] [PubMed]

152. Malchiodi-Albedi, F.; Contrusciere, V.; Raggi, C.; Fecchi, K.; Rainaldi, G.; Paradisi, S.; Matteucci, A.; Santini, M.T.; Sargiacomo, M.; Frank, C.; et al. Lipid raft disruption protects mature neurons against amyloid oligomer toxicity. Biochim. Biophys. Acta 2010, 1802, 406-415. [CrossRef] [PubMed]

153. Cascella, R.; Evangelisti, E.; Bigi, A.; Becatti, M.; Fiorillo, C.; Stefani, M.; Chiti, F.; Cecchi, C. Soluble oligomers require a ganglioside to trigger neuronal calcium overload. J. Alzheimers Dis. 2017, 60, 923-938. [CrossRef] [PubMed]

154. Schengrund, C.L. Lipid rafts: Keys to neurodegeneration. Brain Res. Bull. 2010, 82, 7-17. [CrossRef] [PubMed]

155. Gunther, E.C.; Strittmatter, S.M. Alzheimer amyloid-beta oligomer bound to postsynaptic prion protein activates Fyn to impair neurons. Nat. Neurosci. 2012, 15, 1227-1235.

156. Hong, S.; Ostaszewski, B.L.; Yang, T.; O’Malley, T.T.; Jin, M.; Yanagisawa, K.; Li, S.; Bartels, T.; Selkoe, D.J. Soluble Abeta oligomers are rapidly sequestered from brain ASF in vivo and bind GM1 ganglioside on cellular membranes. Neuron 2014, 82, 308-319. [CrossRef] [PubMed]

157. Calamai, M.; Evangelisti, E.; Cascella, R.; Parenti, N.; Cecchi, C.; Stefani, M.; Pavone, F. Single molecule experiments emphasize GM1 as a key player of the different cytotoxicity of structurally distinct A $\beta 1-42$ oligomers. Biochim. Biophys. Acta 2016, 1858, 386-392. [CrossRef] [PubMed]

158. Fonseca, A.C.R.G.; Moreira, P.I.; Oliveira, C.R.; Cardoso, S.M.; Pinton, P.; Pereira, C.F. Amyloid-beta disrupts calcium and redox homeostasis in brain endothelial cells. Mol. Neurobiol. 2015, 51, 610-622. [CrossRef] [PubMed]

159. Ranjan, B.; Chong, K.H.; Zheng, J. Composite mathematical modeling of calcium signaling behind neuronal cell death in Alzheimer's disease. BMC Syst. Biol. 2018, 12, 10. [CrossRef]

160. Yang, L.; Wang, Z.; Wang, B.; Justice, N.J.; Zheng, H. Amyloid precursor protein regulates Cav1.2 L-type calcium channel levels and function to influence GABAergic short-term plasticity. J. Neurosci. 2009, 29, 15660-15668. [CrossRef] [PubMed]

161. Arispe, N.; Rojas, E.; Pollard, H.B. Alzheimer disease amyloid beta protein forms calcium channels in bilayer membranes: Blockade by tromethamine and aluminum. Proc. Natl. Acad. Sci. USA 1993, 90, 567-571. [CrossRef]

162. Bhatia, R.; Lin, H.; Lal, R. Fresh and globular amyloid beta protein (1-42) induces rapid cellular degeneration: Evidence for Abeta P channel-mediated cellular toxicity. FASEB J. 2000, 14, 1233-1243. [CrossRef] [PubMed]

163. Kagan, B.L.; Hirakura, Y.; Azimov, R.; Azimova, R.; Lin, M.C. The channel hypothesis of Alzheimer's disease: Current status. Peptides 2002, 23, 1311-1315. [CrossRef]

164. Arispe, N.; Diaz, J.C.; Simakova, O. Abeta ion channels. Prospects for treating Alzheimer's disease with Abeta channel blockers. Biochim. Biophys. Acta 2007, 1768, 1952-1965. [CrossRef] [PubMed]

165. Sokolov, Y.; Kozak, J.A.; Kayed, R.; Chanturiya, A.; Glabe, C.; Hall, J.E. Soluble amyloid oligomers increase bilayer conductance by altering dielectric structure. J. Gen. Physiol. 2006, 128, 637-647. [CrossRef] [PubMed] 
166. Samad, N.; Ishaq, S.; Bano, S.; Manzoor, N. Calcium Regulation in Alzheimer's Disease: Mechanistic Understanding. J. Coll. Physicians Surg. Pak. 2017, 27, 566-571.

167. Reese, L.C.; Taglialatela, G. A role for calcineurin in Alzheimer's disease. Curr. Neuropharmacol. 2011, 9, 685-692. [CrossRef]

168. Yin, Y.; Gao, D.; Wang, Y.; Wang, Z.H.; Wang, X.; Ye, J.; Wu, D.; Fang, L.; Pi, G.; Yang, Y.; et al. Tau accumulation induces synaptic impairment and memory deficit by calcineurin-mediated inactivation of nuclear CaMKIV/CREB signaling. Proc. Natl. Acad. Sci. USA 2016, 113, E3773-E3781. [CrossRef]

169. Cavallucci, V.; Berretta, N.; Nobili, A.; Nisticò, R.; Mercuri, N.B.; D'Amelio, M. Calcineurin inhibition rescues early synaptic plasticity deficits in a mouse model of Alzheimer's disease. NeuroMol. Med. 2013, 15, 541-548. [CrossRef]

170. Li, X.G.; Hong, X.Y.; Wang, Y.L.; Zhang, S.J.; Zhang, J.F.; Li, X.C.; Liu, Y.C.; Sun, D.S.; Feng, Q.; Ye, J.W.; et al. Tau accumulation triggers STAT1-dependent memory deficits by suppressing NMDA receptor expression. EMBO Rep. 2019, 20, e47202. [CrossRef] [PubMed]

171. Lin, L.; Cao, J.; Yang, S.S.; Fu, Z.Q.; Zeng, P.; Chu, J.; Ning, L.N.; Zhang, T.; Shi, Y.; Tian, Q.; et al. Endoplasmic reticulum stress induces spatial memory deficits by activating GSK-3. J. Cell. Mol. Med. 2018, 22, 3489-3502. [CrossRef]

172. Liu, Z.C.; Chu, J.; Lin, L.; Song, J.; Ning, L.N.; Luo, H.B.; Yang, S.; Shi, Y.; Wang, Q.; Qu, N.; et al. SIL1 rescued bip elevation-related tau hyperphosphorylation in ER stress. Mol. Neurobiol. 2016, 53, 983-994. [CrossRef] [PubMed]

173. Zhang, Z.; Li, X.G.; Wang, Z.H.; Song, M.; Yu, S.P.; Kang, S.S.; Liu, X.; Zhang, Z.; Xie, M.; Liu, G.P.; et al. $\delta$-Secretase-cleaved Tau stimulates A $\beta$ production via upregulating STAT1-BACE1 signaling in Alzheimer's disease. Mol. Psychiatry 2021, 26, 586-603. [CrossRef] [PubMed]

174. Galla, L.; Redolfi, N.; Pozzan, T.; Pizzo, P.; Greotti, E. Intracellular calcium dysregulation by the Alzheimer's disease-linked protein presenilin 2. Int. J. Mol. Sci. 2020, 21, 770. [CrossRef]

175. Gaspar, P.; Ben Jelloun, N.; Febvret, A. Sparing of the dopaminergic neurons containing calbindin-D28k and of the dopaminergic mesocortical projections in weaver mutant mice. Neuroscience 1994, 61, 293-305. [CrossRef]

176. Damier, P.; Hirsch, E.C.; Agid, Y.; Graybiel, A.M. The substantia nigra of the human brain. II. Patterns of loss of dopaminecontaining neurons in Parkinson's disease. Brain 1999, 122, 1437-1448. [CrossRef] [PubMed]

177. Foehring, R.C.; Zhang, X.F.; Lee, J.C.; Callaway, J.C. Endogenous calcium buffering capacity of substantia nigral dopamine neurons. J. Neurophysiol. 2009, 102, 2326-2333. [CrossRef] [PubMed]

178. Liu, J.; Chang, L.; Song, Y.; Li, H.; Wu, Y. The role of NMDA receptors in Alzheimer's disease. Front. Neurosci. $2019,13,43$. [CrossRef] [PubMed]

179. Lombardo, S.; Maskos, U. Role of the nicotinic acetylcholine receptor in Alzheimer's disease pathology and treatment. Neuropharmacology 2015, 96, 255-262. [CrossRef]

180. Hermann, D.; Mezler, M.; Müller, M.K.; Wicke, K.; Gross, G.; Draguhn, A.; Bruehl, C.; Nimmrich, V. Synthetic A $\beta$ oligomers (A $\beta 1-42$ globulomer) modulate presynaptic calcium currents: Prevention of A $\beta$-induced synaptic deficits by calcium channel blockers. Eur. J. Pharmacol. 2013, 702, 44-55. [CrossRef] [PubMed]

181. Ueda, K.; Shinohara, S.; Yagami, T.; Asakura, K.; Kawasaki, K. Amyloid beta protein potentiates Ca ${ }^{2+}$ influx through L-type voltage-sensitive $\mathrm{Ca}^{2+}$ channels: A possible involvement of free radicals. J. Neurochem. 1997, 68, 265-271. [CrossRef]

182. Willis, M.; Kaufmann, W.A.; Wietzorrek, G.; Hutter-Paier, B.; Moosmang, S.; Humpel, C.; Hofmann, F.; Windisch, M.; -Günther Knaus, H.; Marksteiner, J. L-type calcium channel CaV 1.2 in transgenic mice overexpressing human AbetaPP751 with the London (V717I) and Swedish (K670M/N671L) mutations. J. Alzheimers Dis. 2010, 20, 1167-1180. [CrossRef]

183. Kim, S.; Rhim, H. Effects of amyloid- $\beta$ peptides on voltage-gated L-type $\mathrm{Ca}(\mathrm{V}) 1.2$ and $\mathrm{Ca}(\mathrm{V}) 1.3 \mathrm{Ca}(2+)$ channels. Mol. Cells 2011, 32, 289-294. [CrossRef]

184. Lüscher, C.; Malenka, R.C. NMDA receptor-dependent long-term potentiation and long-term depression (LTP/LTD). Cold Spring Harb. Perspect. Biol. Med. 2012, 4, a005710. [CrossRef] [PubMed]

185. Kelly, B.L.; Ferreira, A. Beta-Amyloid-induced dynamin 1 degradation is mediated by N-methyl-D-aspartate receptors in hippocampal neurons. J. Biol. Chem. 2006, 281, 28079-28089. [CrossRef] [PubMed]

186. De Felice, F.G.; Velasco, P.T.; Lambert, M.P.; Viola, K.; Fernandez, S.J.; Ferreira, S.T.; Klein, W.L. Abeta oligomers induce neuronal oxidative stress through an $N$-methyl-D-aspartate receptor-dependent mechanism that is blocked by the Alzheimer drug memantine. J. Biol. Chem. 2007, 282, 11590-11601. [CrossRef] [PubMed]

187. Parpura-Gill, A.; Beitz, D.; Uemura, E. The inhibitory effects of beta-amyloid on glutamate and glucose uptakes by cultured astrocytes. Brain Res. 1997, 754, 65-71. [CrossRef]

188. Fernández-Tomé, P.; Brera, B.; Arévalo, M.A.; de Ceballos, M.L. Beta-amyloid25-35 inhibits glutamate uptake in cultured neurons and astrocytes: Modulation of uptake as a survival mechanism. Neurobiol. Dis. 2004, 15, 580-589. [CrossRef] [PubMed]

189. Kervern, M.; Angeli, A.; Nicole, O. Selective impairment of some forms of synaptic plasticity by oligomeric amyloid- $\beta$ peptide in the mouse hippocampus: Implication of extrasynaptic NMDA receptors. J. Alzheimers Dis. 2012, 32, 183-196. [CrossRef] [PubMed]

190. Fani, G.; Mannini, B.; Vecchi, G.; Cascella, R.; Cecchi, C.; Dobson, C.M.; Vendruscolo, M.; Chiti, F. A $\beta$ Oligomers Dysregulate Calcium Homeostasis by Mechanosensitive Activation of AMPA and NMDA Receptors. ACS Chem. Neurosci. 2021, 12, 766-781. [CrossRef] [PubMed] 
191. Ferreira, I.L.; Bajouco, L.M.; Mota, S.I.; Auberson, Y.P.; Oliveira, C.R.; Rego, A.C. Amyloid beta peptide 1-42 disturbs intracellular calcium homeostasis through activation of GluN2B-containing $N$-methyl-d-aspartate receptors in cortical cultures. Cell Calcium 2012, 51, 95-106. [CrossRef] [PubMed]

192. Costa, R.O.; Ferreiro, E.; Martins, I.; Santana, I.; Cardoso, S.M.; Oliveira, C.R.; Pereira, C.M.F. Amyloid $\beta$-induced ER stress is enhanced under mitochondrial dysfunction conditions. Neurobiol. Aging 2012, 33, 824.e5-824.e16. [CrossRef] [PubMed]

193. Ferreira, S.T.; Lourenco, M.V.; Oliveira, M.M.; De Felice, F.G. Soluble amyloid-ßoligomers as synaptotoxins leading to cognitive impairment in Alzheimer's disease. Front. Cell. Neurosci. 2015, 26, 191.

194. Nomura, I.; Kato, N.; Kita, T.; Takechi, H. Mechanism of impairment of long-term potentiation by amyloid $\beta$ is independent of NMDA receptors or voltage-dependent calcium channels in hippocampal CA1 pyramidal neurons. Neurosci. Lett. 2005, 391, 1-6. [CrossRef] [PubMed]

195. Liu, L.; Feng, D.; Chen, G.; Chen, M.; Zheng, Q.; Song, P.; Ma, Q.; Zhu, C.; Wang, R.; Qi, W.; et al. Mitochondrial outer-membrane protein FUNDC1 mediates hypoxia-induced mitophagy in mammalian cells. Nat. Cell Biol. 2012, 14, 177-185. [CrossRef] [PubMed]

196. Bezprozvanny, I.; Hiesinger, P.R. The synaptic maintenance problem: Membrane recycling, $\mathrm{Ca}^{2+}$ homeostasis and late onset degeneration. Mol. Neurodegener. 2013, 8, 23. [CrossRef] [PubMed]

197. Lipton, S.A. Paradigm shift in neuroprotection by NMDA receptor blockade: Memantine and beyond. Nat. Rev. Drug Discov. 2006, 5, 160-170. [CrossRef]

198. Francis, P.T. Glutamatergic approaches to the treatment of cognitive and behavioural symptoms of Alzheimer's disease. Neurodegener. Dis. 2008, 5, 241-243. [CrossRef] [PubMed]

199. Mota, S.I.; Ferreira, I.L.; Pereira, C.; Oliveira, C.R.; Rego, A.C. Amyloid-beta peptide1-42 causes microtubule deregulation through N-methyl-D-aspartate receptors in mature hippocampal cultures. Curr. Alzheimer Res. 2012, 9, 844-856. [CrossRef] [PubMed]

200. Paschen, W. Endoplasmic reticulum: A primary target in various acute disorders and degenerative diseases of the brain. Cell Calcium 2003, 34, 365-383. [CrossRef]

201. Verkhratsky, A. The endoplasmic reticulum and neuronal calcium signaling. Cell Calcium 2002, 32, 393-404. [CrossRef]

202. Chakroborty, S.; Goussakov, I.; Miller, M.B.; Stutzmann, G.E. Deviant ryanodine receptor-mediated calcium release resets synaptic homeostasis in presymptomatic3xTg-AD mice. J. Neurosci. 2009, 29, 9458-9470. [CrossRef]

203. Ferreiro, E.; Oliveira, C.R.; Pereira, C. Involvement of endoplasmic reticulum $\mathrm{Ca}^{2+}$ release through ryanodine and inositol 1,4,5-triphosphate receptors in the neurotoxic effects induced by the amyloid-beta peptide. J. Neurosci. Res. 2004, 76, 872-880. [CrossRef] [PubMed]

204. Ferreiro, E.; Resende, R.; Costa, R.; Oliveira, C.R.; Pereira, C.M. An endoplasmicreticulum-specific apoptotic pathway is involved in prion and amyloid-beta peptides neurotoxicity. Neurobiol. Dis. 2006, 23, 669-678. [CrossRef] [PubMed]

205. Supnet, C.; Grant, J.; Kong, H.; Westaway, D.; Mayne, M. Amyloid-beta-(1-42) increases ryanodine receptor-3 expression and function in neurons of TgCRND8 mice. J. Biol. Chem. 2006, 281, 38440-38447. [CrossRef]

206. Paula-Lima, A.C.; Adasme, T.; SanMartín, C. Amyloid $\beta$-peptide oligomers stimulate RyR-mediated Ca ${ }^{2+}$ release inducing mitochondrial fragmentation in hippocampal neurons and prevent RyR-mediated dendritic spine remodeling produced by BDNF. Antioxid. Redox Signal. 2011, 14, 1209-1223. [CrossRef] [PubMed]

207. Wang, X.; Zheng, W. $\mathrm{Ca}\left({ }^{2+}\right)$ homeostasis dysregulation in Alzheimer's disease: A focus on plasma membrane and cell organelles. FASEB J. 2019, 33, 6697-6712. [CrossRef] [PubMed]

208. Kelly, J.F.; Furukawa, K.; Barger, S.W.; Rengen, M.R.; Mark, R.J.; Blanc, E.M.; Roth, G.S.; Mattson, M.P. Amyloid beta-peptide disrupts carbachol induced muscarinic cholinergic signal transduction in control neurons. Proc. Natl. Acad. Sci. USA 1996, 93, 6753-6758. [CrossRef] [PubMed]

209. Paschen, W. Dependence of vital cell function on endoplasmic reticulum calcium levels: Implications for the mechanisms underlying neuronal cell injury in different pathological states. Cell Calcium 2001, 29, 1-11. [CrossRef] [PubMed]

210. Pannaccione, A.; Secondo, A.; Molinaro, P.; D’Avanzo, C.; Cantile, M.; Esposito, A.; Boscia, F.; Scorziello, A.; Sirabella, R.; di Renzo, G.; et al. A new concept: A $\beta 1-42$ generates a Hyperfunctional proteolytic NCX3 fragment that delays caspase-12 activation and neuronal death. J. Neurosci. 2012, 32, 10609-10617. [CrossRef] [PubMed]

211. Ito, E.; Oka, K.; Etcheberrigaray, R.; Nelson, T.J.; McPhie, D.L.; Tofel-Grehl, B.; Gibson, G.E.; Alkon, D.L. Internal Ca ${ }^{2+}$ mobilization is altered in fibroblasts from patients with Alzheimer disease. Proc. Natl. Acad. Sci. USA 1994, 91, 534-538. [CrossRef]

212. Hirashima, N.; Etcheberrigaray, R.; Bergamaschi, S.; Racchi, M.; Battaini, F.; Binetti, G.; Govoni, S.; Alkon, D.L. Calcium responses in human fibroblasts: A diagnostic molecular profile for Alzheimer's disease. Neurobiol. Aging 1996, 17, 549-555. [CrossRef]

213. Rizzuto, R.; De Stefani, D.; Raffaello, A.; Mammucari, C. Mitochondria as sensors and regulators of calcium signalling. Nat. Rev. Mol. Cell Biol. 2012, 13, 566-578. [CrossRef] [PubMed]

214. Görlach, A.; Bertram, K.; Hudecova, S.; Krizanova, O. Calcium and ROS: A mutual interplay. Redox Biol. $2015,6,260-271$. [CrossRef] [PubMed]

215. Goldstein, J.C.; Waterhouse, N.J.; Juin, P.; Evan, G.I.; Green, D.R. The coordinate release of cytochrome c during apoptosis is rapid, complete and kinetically invariant. Nat. Cell Biol. 2000, 2, 156-162. [CrossRef] [PubMed]

216. Yao, J.; Irwin, R.W.; Zhao, L.; Nilsen, J.; Hamilton, R.T.; Brinton, R.D. Mitochondrial bioenergetic deficit precedes Alzheimer's pathology in female mouse model of Alzheimer's disease. Proc. Natl. Acad. Sci. USA 2009, 106, 14670-14675. [CrossRef] [PubMed] 
217. Atamna, H.; Frey, W.H. 2nd Mechanisms of mitochondrial dysfunction and energy deficiency in Alzheimer's disease. Mitochondrion 2007, 7, 297-310. [CrossRef] [PubMed]

218. Xie, H.; Guan, J.; Borrelli, L.A.; Xu, J.; Serrano-Pozo, A.; Bacskai, B.J. Mitochondrial alterations near amyloid plaques in an Alzheimer's disease mouse model. J. Neurosci. 2013, 33, 17042-17051. [CrossRef] [PubMed]

219. Santos, R.X.; Correia, S.C.; Wang, X.; Perry, G.; Smith, M.A.; Moreira, P.I.; Zhu, X. A synergistic dysfunction of mitochondrial fission/fusion dynamics and mitophagy in Alzheimer's disease. J. Alzheimers Dis. 2010, 20, S401-S412. [CrossRef] [PubMed]

220. Kopeikina, K.J.; Carlson, G.A.; Pitstick, R.; Ludvigson, A.E.; Peters, A.; Luebke, J.I.; Koffie, R.M.; Frosch, M.P.; Hyman, B.T.; Spires-Jones, T.L. Tau accumulation causes mitochondrial distribution deficits in neurons in a mouse model of tauopathy and in human Alzheimer's disease brain. Am. J. Pathol. 2011, 179, 2071-2082. [CrossRef] [PubMed]

221. Brown, M.R.; Sullivan, P.G.; Geddes, J.W. Synaptic mitochondria are more susceptible to $\mathrm{Ca}^{2+}$ overload than nonsynaptic mitochondria. J. Biol. Chem. 2006, 281, 11658-11668. [CrossRef] [PubMed]

222. Zervas, M.; Opitz, T.; Edelmann, W.; Wanier, B.; Kucherlapati, R.; Stanton, P.K. Impaired hippocampal long-term potentiation in microtubule-associated protein 1B-deficient mice. J. Neurosci. Res. 2005, 82, 83-92. [CrossRef] [PubMed]

223. Fukunaga, K.; Muller, D.; Miyamoto, E. CaM kinase II in long-term potentiation. Neurochem. Int. 1996, 28, 343-358. [CrossRef]

224. Sanz-Blasco, S.; Valero, R.A.; Rodriguez-Crespo, I.; Villalobos, C.; Nunez, L. Mitochondrial Ca ${ }^{2+}$ overload underlies Abeta oligomers neurotoxicity providing an unexpected mechanism of neuroprotection by NSAIDs. PLoS ONE 2008, 3, e2718. [CrossRef] [PubMed]

225. Calvo-Rodriguez, M.; Garcia-Durillo, M.; Villalobos, C.; Nunez, L. Aging enables Ca ${ }^{2+}$ overload and apoptosis induced by amyloid-beta oligomers in rat hippocampal neurons: Neuroprotection by non-steroidal anti-inflammatory drugs and Rflurbiprofen in aging neurons. J. Alzheimers Dis. 2016, 54, 207-221. [CrossRef] [PubMed]

226. Ferreiro, E.; Oliveira, C.R.; Pereira, C.M. The release of calcium from the endoplasmic reticulum induced by amyloid-beta and prion peptides activates the mitochondrial apoptotic pathway. Neurobiol. Dis. 2008, 30, 331-342. [CrossRef] [PubMed]

227. Calvo-Rodriguez, M.; Hou, S.S.; Snyder, A.C.; Kharitonova, E.K.; Russ, A.N.; Das, S.; Fan, Z.; Muzikansky, A.; Garcia-Alloza, M.; Serrano-Pozo, A.; et al. Increased mitochondrial calcium levels associated with neuronal death in a mouse model of Alzheimer's disease. Nat. Commun. 2020, 11, 2146. [CrossRef] [PubMed]

228. Supnet, C.; Bezprozvanny, I. Neuronal calcium signaling, mitochondrial dysfunction and Alzheimer's disease. J. Alzheimers Dis. 2010, 20 (Suppl. S2), S487-S498. [CrossRef] [PubMed]

229. Area-Gomez, E.; De Groof, A.; Bonilla, E.; Montesinos, J.; Tanji, K.; Boldogh, I.; Pon, L.; Schon, E.A. A key role for MAM in mediating mitochondrial dysfunction in alzheimer disease. Cell Death Dis. 2018, 9, 335. [CrossRef] [PubMed] 